\title{
Understanding and Predicting the Orientation of Heteroleptic Phosphors in Organic Light- Emitting Materials
}

\author{
Matthew J. Jurow, ${ }^{1}$ Christian Mayr, ${ }^{2}$ Tobias D. Schmidt, ${ }^{2}$ Thomas Lampe,${ }^{2}$ Peter I. Djurovich, ${ }^{1}$ \\ Wolfgang Brütting, ${ }^{2}$ Mark E. Thompson*1 \\ ${ }^{1}$ Department of Chemistry, University of Southern California, Los Angeles, California 90089, \\ United States \\ ${ }^{2}$ Institute of Physics, University of Augsburg 86135, Augsburg, Germany
}

\begin{abstract}
Controlling the alignment of the emitting molecules used as dopants in organic LEDs is an effective strategy to improve the outcoupling efficiency of these devices. To explore the mechanism behind the orientation of dopants into host organic layers, we synthesized a coumarin-based ligand that was cyclometallated onto an iridium core to form three phosphorescent heteroleptic molecules, (bppo $)_{2} \operatorname{Ir}(\mathrm{acac}),(\mathrm{bppo})_{2} \operatorname{Ir}(\mathrm{ppy})$ and (ppy) ${ }_{2} \operatorname{Ir}(\mathrm{bppo})$ (bppo = benzopyranopyridinone, ppy $=2$-phenylpyridinate and acac $=$ acetylacetonate $)$. Each emitter was doped into a 4,4'-bis(N-carbazolyl)-1,1'-biphenyl (CBP) host layer, and the resultant orientation of their transition dipole moment vectors was measured by angular dependent ppolarized photoluminescent emission spectroscopy. In solid films, (bppo) $)_{2} \operatorname{Ir}(\mathrm{acac})$ is found to have a largely horizontal transition dipole vector orientation relative to the substrate, while (ppy)2 $\operatorname{Ir}($ bppo) and (bppo)2 $\operatorname{Ir}(\mathrm{ppy})$ are isotropic. We propose that the inherent asymmetry at the surface of the growing film promotes dopant alignment in these otherwise amorphous films. Modeling the net orientation of the transition dipole moments of these materials yields general design rules for further improving horizontal orientation.
\end{abstract}




\section{Introduction}

Molecular orientation and solid state morphology exert a significant impact on the performance of molecular electronic devices. ${ }^{1-5}$ The use of phosphorescent iridium complexes with near unity electroluminescence quantum yields as emitters in modern OLEDs has allowed for the manufacture of devices with excellent efficiencies. ${ }^{6,7}$ Despite the high internal quantum efficiency, approximately $80 \%$ of photons are trapped inside the thin-film structure and lost to surface plasmons and waveguide modes. To reduce the incidence of photons being dissipated to these loss channels, and enhance external quantum efficiencies (EQE), outcoupling technologies have been successfully employed. ${ }^{8-10}$ An alternative strategy to address this problem is to intrinsically increase the outcoupling efficiency through control of the direction of light emission. The organometallic molecules at the core of these devices emit light perpendicular to their transition dipole moment vector (TDV). ${ }^{4,11}$ Orienting emissive molecules with transition dipoles parallel to the substrate would eliminate the need for micro-lens arrays, gratings, or other physical methods used to enhance outcoupling, and allow for large scale manufacture of OLEDs with high external quantum efficiencies. ${ }^{4,8,9,12-14}$

Isotropic dopant orientation is observed in films of facial tris-iridium phenylpyridine $\left(\operatorname{Ir}(\text { ppy })_{3}\right)$ and many other homoleptic tris-cyclometalated Ir dopants. ${ }^{15-17}$ Heteroleptic complexes of the formula $\left(\mathrm{C}^{\wedge} \mathrm{N}\right)_{2} \operatorname{Ir}\left(\mathrm{O}^{\wedge} \mathrm{O}\right)$, where $\mathrm{C}^{\wedge} \mathrm{N}$ is a cyclometallated ligand and $\mathrm{O}^{\wedge} \mathrm{O}$ is a diketonate ligand such as acetylacetonate (acac), have previously been observed to demonstrate higher EQE than their homoleptic $\operatorname{Ir}\left(\mathrm{C}^{\wedge} \mathrm{N}\right)_{3}$ analogues, because their average TDV are disproportionately horizontal relative to the substrate in solid films. ${ }^{11,16,18-26}$ There are numerous reports of other dopants with ancillary ligands, especially acac and its close analogues, which feature net parallel TDV orientations to various degrees in doped films (see supporting information Table S1 for tabulated literature data). ${ }^{22-25}$

Two mechanisms have been invoked to account for the disparity in the alignment properties of selected dopants in an otherwise amorphous or nearly amorphous host matrix. Past reports have speculated that large dipole moments present in the tris-cyclometalates lead to aggregation that suppresses dopant interactions with the host matrix. ${ }^{16,27-29}$ Other reports have proposed electrostatic interactions between electronegative regions in the $\left(\mathrm{C}^{\wedge} \mathrm{N}\right)_{2} \operatorname{Ir}\left(\mathrm{O}^{\wedge} \mathrm{O}\right)$ complexes and electropositive host structures give rise to macroscopic order and thus dopant 
(and host) alignment. ${ }^{22,30,31}$ We will show that neither the dopant dipole based mechanism nor component electrostatics adequately describe the alignment process and propose a mechanism based on the inherent asymmetry of $\left(\mathrm{C}^{\wedge} \mathrm{N}\right)_{2} \operatorname{Ir}\left(\mathrm{O}^{\wedge} \mathrm{O}\right)$ and some $f a c-\operatorname{Ir}\left(\mathrm{C}^{\wedge} \mathrm{N}\right)_{3}$ complexes that explain the many instances of observed dopant alignment in amorphous host materials.

To explore the mechanism by which these approximately spherical phosphors orient in amorphous host materials we synthesized a coumarin based ligand from which we prepared heteroleptic iridium based emitters: (bppo $)_{2} \operatorname{Ir}(\mathrm{acac}),(\mathrm{bppo})_{2} \operatorname{Ir}(\mathrm{ppy})$ and (ppy) $)_{2} \operatorname{Ir}(\mathrm{bppo})$ where bppo $=$ benzopyranopyridinone, ppy $=2$-phenylpyridinate (Figure 1$)$. The coumarin functionality was employed because the carbonyl $(\mathrm{C}=\mathrm{O})$ group provides a large dipole moment. ${ }^{15,17}$ Each material was doped into a 4,4'-bis $(N$-carbazolyl)1,1'-biphenyl (CBP) host matrix at $2 \%, 6 \%, 12 \%$ and $20 \%(\mathrm{v} / \mathrm{v})$ and characterized by angular dependent p-polarized emission (see methods for details). Analysis reveals that emission from films containing $(\mathrm{bppo})_{2} \operatorname{Ir}(\mathrm{acac})$ is oriented with a net horizontal alignment, while the emission from films with (ppy) $)_{2} \operatorname{Ir}(\text { bppo) and (bppo) })_{2} \operatorname{Ir}(\mathrm{ppy})$ are nearly isotropic, although the dopants have substantial permanent dipole moments and similarly oriented TDVs. Understanding the causes of the observed alignment behavior of the emitted light will allow us to develop dopant

(a)
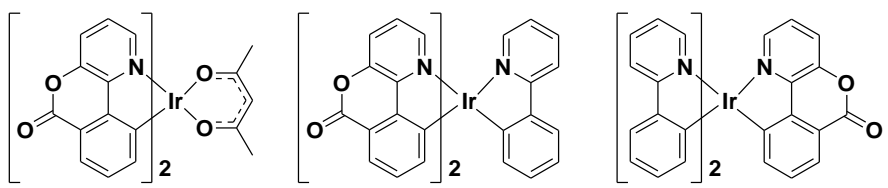

(bppo) ${ }_{2} \operatorname{Ir}(\mathrm{acac})$

(bppo) $)_{2} \operatorname{Ir}($ ppy)

(ppy) $)_{2} \mathbf{I r}(\mathrm{bppo})$

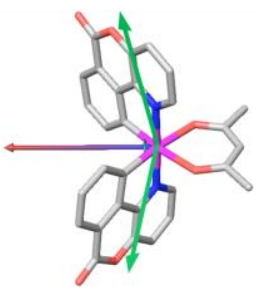

$86^{\circ}$

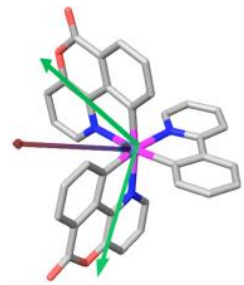

$78^{\circ}, 93^{\circ}$

(c)

(b)

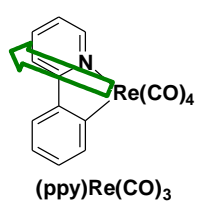

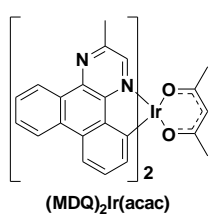

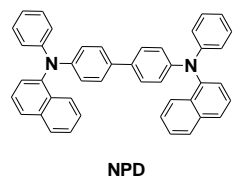

NPD
Figure 1. Material Structure and Properties (a) Structures of phosphorescent dopants used here. Listed below each structure are the angle(s) between the permanent ( $\mu$, red arrows) and transition dipole vectors (TDV, green arrows) for a TDV orientation comparable to that observed in (b) $($ ppy $) \operatorname{Re}(\mathrm{CO})_{4}(\mathrm{TDV}=$ green arrow). The dipole moment of (bppo $)_{2} \operatorname{Ir}(\mathrm{acac})(\mu=6.18$ D) lies along the molecular $\mathrm{C}_{2}$ axis. In (bppo) ${ }_{2} \operatorname{Ir}(\mathrm{ppy})$ the dipole $(\mu=8.44 \mathrm{D})$ is tilted from this axis and lies in a plane of the bppo ligand that is trans to the $\mathrm{C}_{\mathrm{bppo}}$ and $\mathrm{N}_{\text {ppy. }}$. In $\operatorname{Ir}(\mathrm{ppy})_{2}$ (bbpo) the dipole $(\mu=8.25 \mathrm{D})$ lies in the plane of the ppy ligand that is also trans to $\mathrm{C}_{\mathrm{bppo}}$ and $\mathrm{N}_{\text {ppy }}$ but is tilted toward the bppo ligand. (c) Structures of (MDQ) $)_{2} \operatorname{Ir}(\mathrm{acac})$ and NPD. 
molecules that will preferentially orient in films of isotropic materials for diverse uses in photonic devices.

\section{Results}

The synthesis and photophysical properties of (bppo $)_{2} \operatorname{Ir}(\mathrm{ppy})$ and (ppy) ${ }_{2} \operatorname{Ir}(\mathrm{bppo})$ have been reported previously. ${ }^{32}$ A reaction between $\left[\operatorname{Ir}(\text { bppo })_{2}(\mu-\mathrm{Cl})\right]_{2}$ and ppy-H formed both (bppo $)_{2} \operatorname{Ir}(\mathrm{ppy})$ and (ppy) ${ }_{2} \operatorname{Ir}(\mathrm{bppo})$ in moderate yield. Both tris-cyclometalated complexes were isolated as facial isomers, with the (ppy) $)_{2} \operatorname{Ir}(\mathrm{bppo})$ species being a result of ligand scrambling during the course of the reaction. See methods for synthetic details. The Ir complexes exhibit photophysical properties typical of phosphorescent iridium complexes. At room temperature the compounds display strong green-yellow luminescence, and have quantum yields of greater than $88 \%$ and luminescence decay times in the microsecond range in solution (see supplementary information). Ground state dipole moments for the complexes were calculated using Density Functional Theory (DFT, B3LYP-LACVP**) (Figure 1). ${ }^{33-36}$

Films of the complexes doped into CBP were vapor deposited at 2\%,6\%, $12 \%$ and $20 \%$ $(\mathrm{v} / \mathrm{v})$ to probe the impact of dipole moment and heteroleptic substitution on aggregation and concentration quenching. All species have large quantum yields in solid films, greater than $30 \%$ at any doping level tested. Concentration related quenching of photoluminescent quantum yield, along with a bathochromic shift of emission indicative of dopant aggregation in the solid flims, was observed with all species. The extent of the concentration quenching varied between the three dopants, with the (bppo) ${ }_{2} \operatorname{Ir}($ ppy) species showing the largest loss in quantum yield, followed by (bppo $)_{2} \operatorname{Ir}(\mathrm{acac})$ and finally (ppy) $)_{2} \operatorname{Ir}(\mathrm{bppo})$. Since concentration quenching requires an overlap of the emissive ligands, we believe that the (bppo $)_{2} \operatorname{Ir}(\mathrm{ppy})$ demonstrates the largest effect because it has two potentially emissive ligands.

Angle dependent p-polarized emission measurements of doped films by photoluminescent excitation are used to determine the net orientation of the TDVs of emissive dopants. ${ }^{4,12,23,25,37-39}$ We define the value $\Theta$ as the ratio of power radiated by vertical components of the contributing TDVs to the total power radiation. The details of this measurement are given in the Supplementary Materials. A film with isotropic phosphors will yield a value of $\Theta=0.33$. If the emissive TDV is aligned parallel to the substrate $\Theta=0$, while a film with the TDV perpendicular to the substrate will give a $\Theta=1$. Vertically oriented 


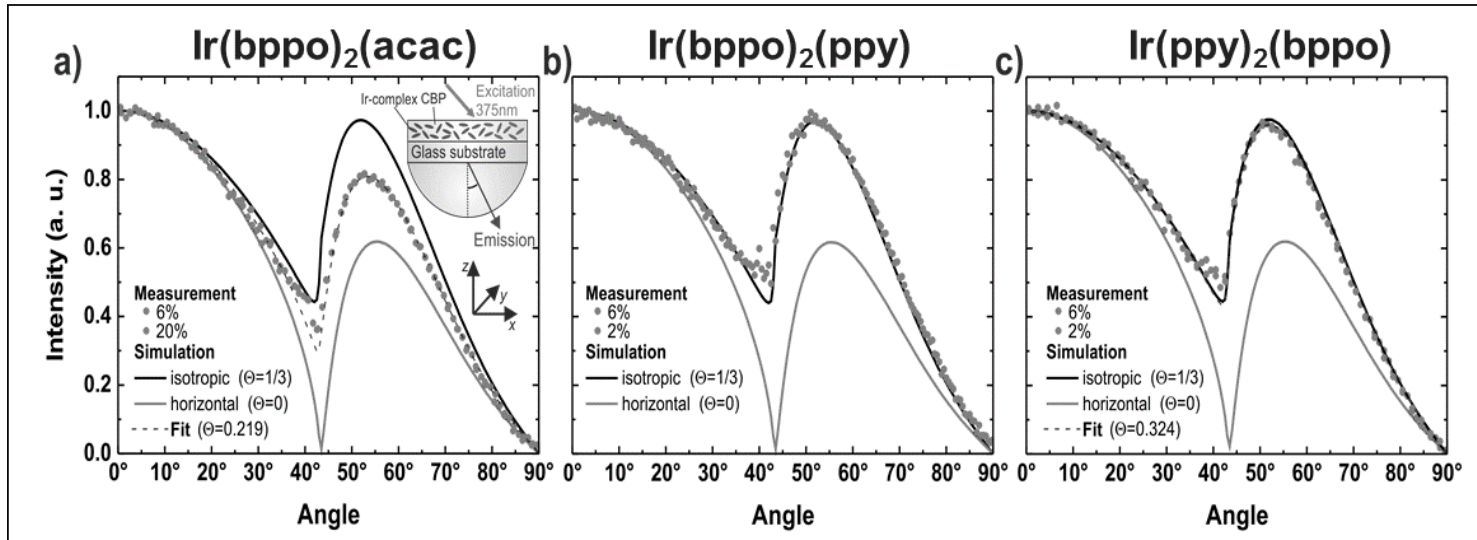

Figure 2. Polarized Emission Spectra Cross-sections of the measurements and simulations of the angular dependent p-polarized PL emission spectra (considering an emission in the $x$ - $z$-plane) for films of $15 \mathrm{~nm}$ CBP doped with (a) (bppo) $)_{2} \operatorname{Ir}($ acac) (at $540 \mathrm{~nm})$, (b) (bppo) $)_{2} \operatorname{Ir}($ ppy) (at $530 \mathrm{~nm}$ ), and (c) (ppy) $)_{2} \operatorname{Ir}($ bppo) (at $550 \mathrm{~nm})$ at different doping levels on glass substrates. The measured data have been fitted (dashed lines) to determine the degree of orientation. (bppo) ${ }_{2} \operatorname{Ir}\left(\right.$ acac) $\Theta=0.22 ;(\text { bppo })_{2} \operatorname{Ir}($ ppy) $\Theta=0.33$; and (ppy) ${ }_{2} \operatorname{Ir}(\mathrm{bppo}) \Theta=0.32$. Inset image depicts experimental design.

transition dipoles couple strongly to surface plasmons in the metal electrodes of the OLED, decreasing the external efficiency of the OLED, therefore the smallest possible value of $\Theta$ is desired. $^{37,40}$

(ppy) $)_{2} \operatorname{Ir}(\mathrm{bppo})$ and (bppo $)_{2} \operatorname{Ir}(\mathrm{ppy})$ were observed to be nearly isotropic at all measured doping levels. Films doped with (bppo) $)_{2} \operatorname{Ir}($ acac) exhibit $\Theta=0.22$ (Figure 2), similar to the value observed for other heteroleptic iridium complexes with $\beta$-diketonate ligands. Interestingly, we observed that films doped with (bppo) ${ }_{2} \operatorname{Ir}(\mathrm{acac})$ exhibit $\Theta=0.22$ independent of doping concentration between $6 \%$ and $20 \%$ with nearly identical line fits, despite being well into the concentration quenched regime (indicative of significant aggregation).

\section{Discussion}

Prior studies have reported that the magnitude of the ground state dipole moment of the emitter effects the degree of aggregation and thus alignment and emission characteristics of iridium complexes in doped films. ${ }^{27}$ The aggregated complexes are proposed to undergo a decreased interaction with the host matrix and randomly orient. ${ }^{41}$ All tested dopants exhibit spectral broadening and concentration quenching due to aggregation (see Supplementary Information), as expected because of their large permanent dipole moments. The concurrent observed red shifted emission in doped films indicates that these aggregates emit photons. The unchanged orientation measured in the extremely concentrated (20\% v/v) (bppo $)_{2} \operatorname{Ir}(\mathrm{acac})$ film 
implies that the lack of aggregation is not responsible for the consistently observed net horizontal TDV orientation of heteroleptic iridium complexes containing an acac ligand.

In order to understand the observed alignment for the bppo and related $\operatorname{Ir}\left(\mathrm{C}^{\wedge} \mathrm{N}\right)_{3}$ and heteroleptic complexes, it is essential to be able to define the orientation of the transition dipole moment relative to the molecular frame, since our optical measurement only gives the relationship of the TDV to the substrate plane. Emission from cyclometallated iridium complexes is due predominantly to a triplet metal-to-ligand-charge-transfer $\left({ }^{3} \mathrm{MLCT}\right)$ transition. In a heteroleptic Ir complex, emission is expected to originate from a ${ }^{3}$ MLCT state involving the ligand(s) with the lowest triplet energy. ${ }^{42}$ Calculated triplet spin density surfaces indicate that all three bppo based complexes considered here emit from a ${ }^{3}$ MLCT state involving a single bppo ligand. The next step is to determine the orientation of the TDV for the "(bppo)Ir" fragment and ultimately to the permanent dipole moment of the molecule. Fortunately, the orientation of the TDV has been determined experimentally for the closely related cyclometallated complex (ppy) $\operatorname{Re}(\mathrm{CO})_{4}$ by examining the polarization of emission obtained from a single crystal. ${ }^{43}$ This Re complex emits from a ${ }^{3}$ MLCT involving the "(ppy)Re" fragment. The TDV was found to lie in the plane of the ppy ligand directed by an angle of $\delta=18.5^{\circ}$ away from the $\operatorname{Re}-\mathrm{N}$ bond axis (Figure 1b). Considering the molecular and photophysical properties of (bppo $)_{2} \operatorname{Ir}(\mathrm{acac})$ are similar to those of (ppy) $)_{2} \operatorname{Ir}(\mathrm{acac})$, the orientation of the transition dipole for the two cyclometalated ligands can then be expected to lie in a similar direction. The electron withdrawing nature of the carbonyl functionality of the bppo ligand is expected to shift the TDV further away from the Ir-N bond than is observed for $(p p y) \operatorname{Re}(\mathrm{CO})_{4}$, thus we expect the bppo based emitters to give an angle between the Ir-N bond and the TDV, defined as $\delta$, between 20 and $40^{\circ}$.

The angles between the permanent and transition dipole moments for each bppo based dopant are illustrated in figure 1(a), assuming a $\delta$ value of $20^{\circ}$. With two identical emissive bppo ligands, (bppo $)_{2} \operatorname{Ir}(\mathrm{acac})$ and (bppo $)_{2} \operatorname{Ir}(\mathrm{ppy})$ have similar angles between their ground state and transition dipole moment vectors, averaging $86^{\circ}$. (ppy) $)_{2} \operatorname{Ir}(\mathrm{bppo})$ has slightly smaller $\delta$ angle of $68^{\circ}$. The similarities of these angles contrasted with the observation that only (bppo $)_{2} \operatorname{Ir}(\operatorname{acac})$ shows a net alignment in doped films further indicates that the permanent molecular dipole is not responsible for dopant alignment in Ir-phosphor based films. 
Previous reports have suggested that simultaneous host and dopant interactions in aligned matrices arises from formation of donor/host aggregates based on the component electrostatics. $^{22,30,31}$ The complexes studied here have very similar electrostatic surfaces (Figure 3). (bppo $)_{2} \operatorname{Ir}(\mathrm{acac})$ and (bppo) ${ }_{2} \operatorname{Ir}(\mathrm{ppy})$, are both dominated by the strongly electronegative coumarin ligand, yet demonstrate quite different orientation behavior in CBP. Thus, component electrostatics is unlikely to be an important factor in alignment for these dopants.

A mechanism for molecular alignment of a growing thin film of neat organic molecules during vacuum deposition has been described previously. ${ }^{44,45}$ These authors propose that molecules with high aspect ratios, such as CBP or NPD preferentially lie with their long axis parallel to the surface, thus minimizing the surface free energy and increasing the film density. The CBP host used here has a comparatively low glass transition temperature $\left(\mathrm{T}_{\mathrm{g}}=62^{\circ}\right),{ }^{46}$ which the previous report predicts should give an isotopic film. A separate recent study has found no dependence of the TDV orientation of two prototypical heteroleptic emitters $\left((\mathrm{ppy}){ }_{2} \operatorname{Ir}(\mathrm{acac})\right.$ and $\left.(\mathrm{MDQ})_{2} \operatorname{Ir}(\mathrm{acac})\right)$ on the $\mathrm{T}_{\mathrm{g}}$ of the host material, with observed dopant ordering resulting from intrinsic properties of the dopant species. ${ }^{17}$

Here we propose a mechanism, extending from previous reports on neat films, ${ }^{44,45}$ that recognizes a surface of an amorphous (isotropic) film as inherently asymmetric during deposition, i.e. organic film versus vacuum, which leads to the alignment of molecules deposited on it. The acac group presents an aliphatic region on the surface of the $\left(\mathrm{C}^{\wedge} \mathrm{N}\right)_{2} \operatorname{Ir}(\mathrm{acac})$ complex, which lies along the molecular $\mathrm{C}_{2}$ axis. We propose that the boundary created between the organic host material on the substrate and the vacuum of the deposition chamber during fabrication causes the asymmetrical $\left(\mathrm{C}^{\wedge} \mathrm{N}\right)_{2} \operatorname{Ir}(\mathrm{acac})$ molecules to orient, before it is over coated with an amorphous layer of the host material.

Molecular rearrangement and alignment on surfaces is known to occur on time scales consistent with this mechanism. ${ }^{44,47-49}$ Note that this mechanism does

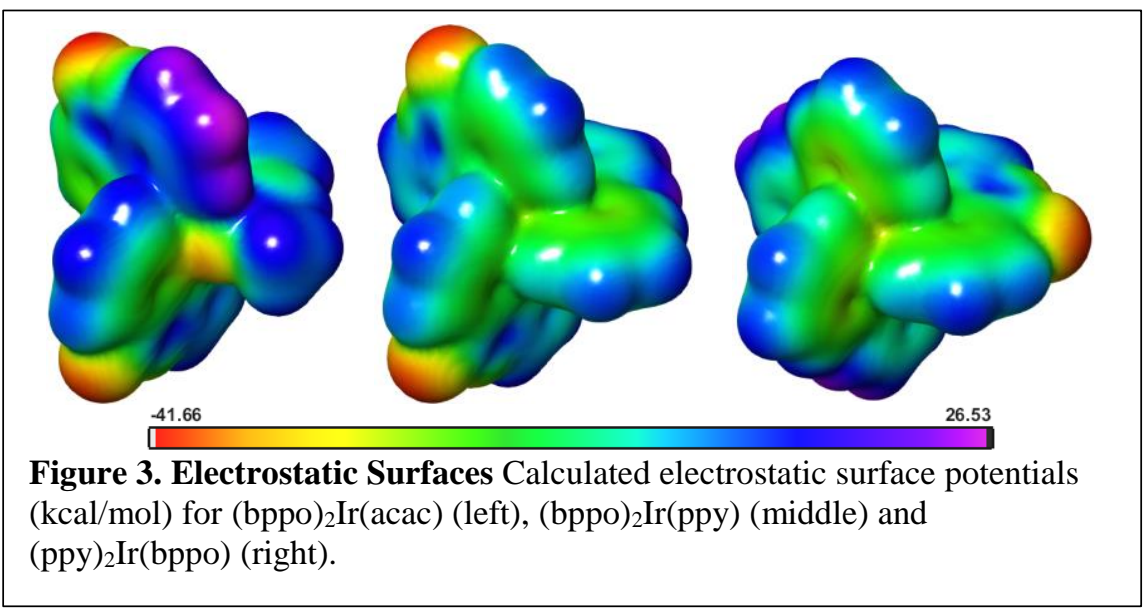


not require any alignment of the host material, and explains why $\left(\mathrm{C}^{\wedge} \mathrm{N}\right)_{2} \operatorname{Ir}\left(\mathrm{O}^{\wedge} \mathrm{O}\right)$ phosphors with widely varied cyclometallating ligands all show dopant alignment (see SI for tabulated values), since the shared $\beta$-diketonate ligand will give a discrete aliphatic surface "patch" in each case.

Support for a surface promoted alignment of dopants is seen in the recent report of an isotropic orientation for ( $\mathrm{ppy})_{2} \operatorname{Ir}(\mathrm{acac})$ when spin cast in a poly-methylmethacrylate (PMMA) matrix (the same dopant gives $\Theta=0.22$ in vapor deposited films). ${ }^{31}$ We have also examined solution deposited films of $\operatorname{Ir}(\mathrm{ppy})_{3}$, (MDQ) $)_{2} \operatorname{Ir}(\mathrm{acac})$ and (bppo $)_{2} \operatorname{Ir}(\mathrm{acac})$ doped in PMMA and found they all give isotropic dopant emission. Previous reports have shown a similar difference when comparing solution processed and thermally evaporated organic thin films, i.e. isotropic and ordered films, respectively, from the two methods. ${ }^{45,50}$ While the isotropic nature of the films processed from solution supports our proposal that an organic/vacuum interface is needed for dopant alignment, it is important to note that the vacuum and solution deposited films are in different host materials. Unfortunately, the poor solubility of CBP prevents direct comparison between vacuum and solution processing. To further test our hypothesis we compared films prepared by both vacuum deposition and spin coating solution of (MDQ) $)_{2} \operatorname{Ir}($ acac) doped into NPD (8\% v/v) (see Scheme). The spin cast films displayed an orientation of $\Theta=0.36$, i.e. nearly isotropic (see SI). When fabricated by vapor deposition, the same system demonstrates horizontal orientation with $\Theta=0.24$, in good agreement with the reported values of alignment for $\left(\mathrm{C}^{\wedge} \mathrm{N}\right)_{2} \operatorname{Ir}$ (acac) dopants. ${ }^{27}$ This result indicates that the vacuum/organic boundary created during vapor deposition is critical to producing the observed alignment in the measured heteroleptic systems.

To assess consequences of dopant alignment we have developed a mathematical representation that illustrates how the orientation of a general $\left(\mathrm{C}^{\wedge} \mathrm{N}\right)_{2} \operatorname{Ir}(\operatorname{acac})$ and $f a c-\operatorname{Ir}\left(\mathrm{C}^{\wedge} \mathrm{N}\right)_{3}$ complexes affects $\Theta$ for any molecular orientation and any given TDV. The coordinate system and direction of rotation for the molecules around angles $\varepsilon$ and $\varphi$ are defined in figure 4 , with the $\mathrm{z}$ axis orthogonal to the substrate. The model assumes that the TDV lies in the plane of the $\left(\mathrm{C}^{\wedge} \mathrm{N}\right) \mathrm{Ir}$ ligands at an angle $\delta$ between the $\mathrm{Ir}-\mathrm{N}$ bond and TDV. To probe the dependence of $\Theta$ on molecular orientation for various values of $\delta$, the metal complex is rotated in the imposed coordinate system and $\Theta$ is calculated for the molecule using Eqn. S1. The starting point for both types of complexes $\left(\varepsilon=\varphi=0^{\circ}\right)$ is depicted in figure 4 . The molecules were rotated around $\varepsilon$ 
in steps and $\Theta$ was calculated from the projection of the TDV of the emissive ligand(s) onto the $\mathrm{x}, \mathrm{y}$, and $\mathrm{z}$ directions at each step in $\varepsilon$ for $\varphi$. Figure 4 shows one quadrant of the possible $\varepsilon$ and $\varphi$ values, full plots for $\varepsilon, \varphi=0-360^{\circ}$ are presented in the supporting information (Figures $\mathrm{S} 15$, S16).

For $\left(\mathrm{C}^{\wedge} \mathrm{N}\right)_{2} \operatorname{Ir}\left(\mathrm{O}^{\wedge} \mathrm{O}\right)$ complexes, values of $\Theta$ with $\delta<10^{\circ}$ are insensitive to rotation around $\varepsilon$ but vary with changes in $\varphi$ (Figure 4(a)). As the magnitude of $\delta$ increases, a dependence of $\Theta$ upon rotation around $\varepsilon$ appears. Regions of low $\Theta$ become localized near values of $\varepsilon=135^{\circ}$, which places the $\mathrm{C}_{2}$ axis in the $\mathrm{x}-\mathrm{y}$ plane, parallel to the substrate. The mechanism we propose for dopant alignment predicts that the (bppo) $)_{2} \operatorname{Ir}(\mathrm{acac})$ molecules will orient with the $\mathrm{C}_{2}$ axis perpendicular to the substrate. We expect the bppo based emitters to have values of $\delta$ between 20 and $40^{\circ}$ (vide supra). Examination of the plots in figure 4a show that if the (bppo) ${ }_{2} \operatorname{Ir}(\mathrm{acac})$ dopants exhibited uniform alignment with their $\mathrm{C}_{2}$ axes orthogonal to the substrate $\left(\varepsilon=45^{\circ}\right.$ and $\left.\varphi=0^{\circ}\right)$, then $\Theta$ would be less than 0.22 for any value of $\delta \leq 40^{\circ}$. The experimental values of $\Theta$ is higher than predicted likely comes for two sources. First, random variation away from orthogonal order is expected for a population of molecules, which will shift the net orientation toward isotropic. Second, film roughness in much the same way contributes to a deviation toward an isotropic alignment. Examination of the CBP and doped CBP films by Atomic Force Microscopy (AFM) shows that the organic films are not flat but have an RMS roughness of $2.2 \mathrm{~nm}$. We have evaluated random traces of the AFM image for an $8 \%$ doped CBP film (see supporting information, Figure S14) and determined the average angle the CBP surface takes relative to the substrate surface is $5.2^{\circ}+/-0.3^{\circ}$. Both of these factors are expected to shift the net molecular orientation away from the ideal $\varepsilon=45^{\circ}$ and $\varphi=0^{\circ}$ toward a more isotropic value. Note that when $\varepsilon<45^{\circ}$, only a small increase in $\varphi$ is needed to obtain $\Theta=0.22$ for $\delta$ values between $30^{\circ}$ and $40^{\circ}$.

In contrast to $\left(\mathrm{C}^{\wedge} \mathrm{N}\right)_{2} \operatorname{Ir}\left(\mathrm{O}^{\wedge} \mathrm{O}\right)$ complexes, $f a c-\operatorname{Ir}\left(\mathrm{C}^{\wedge} \mathrm{N}\right)_{3}$ complexes with a TDV oriented along either metal-ligand bonds $(\delta=0,90)$ will yield a $\Theta$ value of 0.33 for all molecular orientations (Figure 4(b)). In this case, the emission isotropy of a perfectly aligned emitter will be experimentally indistinguishable from a randomly oriented one. As the TDV deviates from 


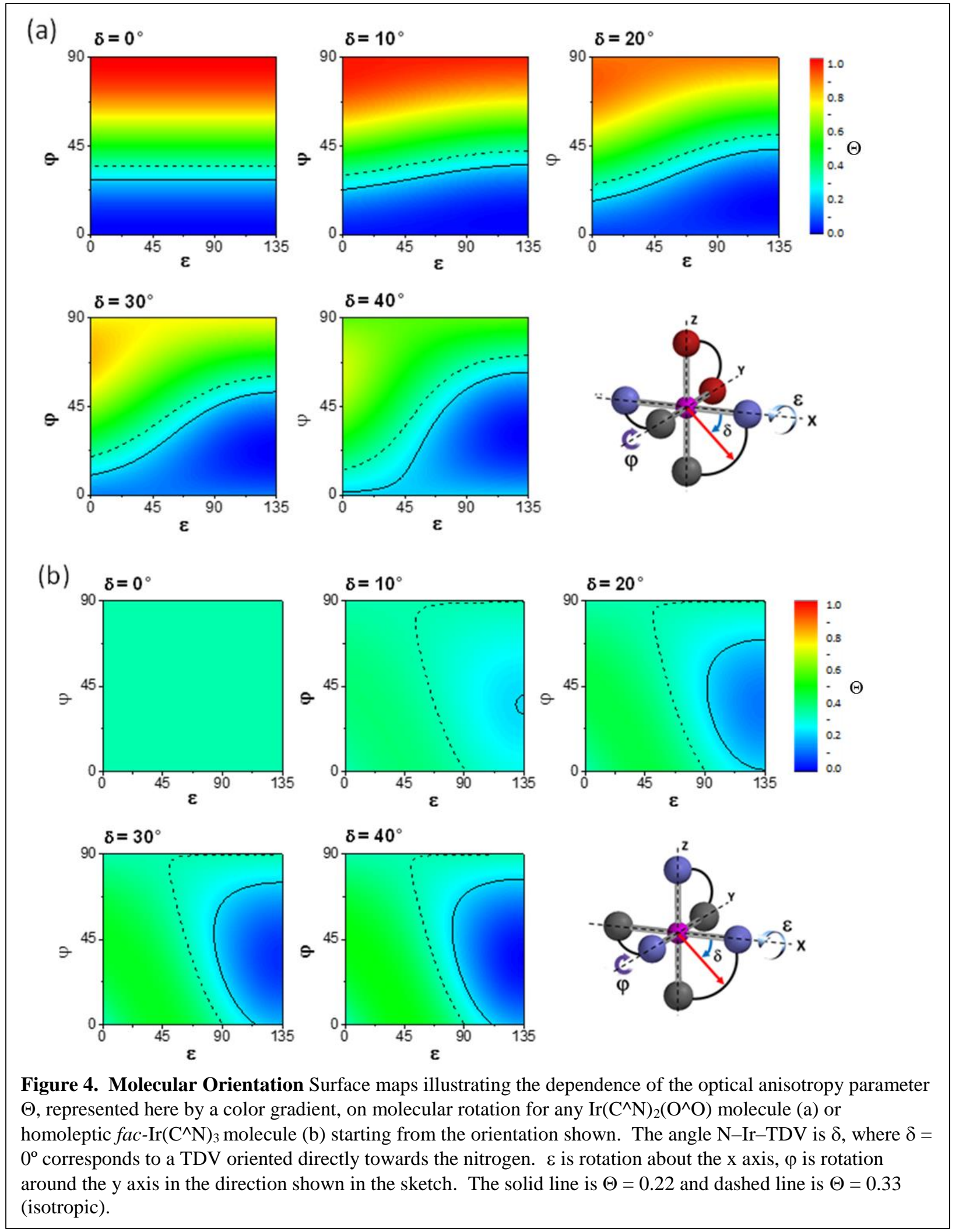

the metal-ligand bond axis $(90>\delta>0)$, regions of low $\Theta$ appear centered at angles of $\varepsilon=135^{\circ}$ 
and $\varphi=35.3^{\circ}$ corresponding to a molecular geometry with $\mathrm{C}_{3}$ axis perpendicular to the $\mathrm{x}-\mathrm{y}$ plane.

There are two examples of facial homoleptic complexes that are reported to show substantial alignment in doped films (see $\operatorname{Ir}(\text { chpy })_{3}$ and $\operatorname{Ir}(\text { piq })_{3}$ in Figure 5 and table $\mathrm{S} 1$ ). The $\Theta$ values for the two dopants are 0.23 and 0.22 , respectively. ${ }^{27}$ The two complexes have $\mathrm{C}^{\wedge} \mathrm{N}$ ligands that give rise to substantial structural anisotropy in the facial-trischelated complexes, similar to heteroleptic species, as can be seen in the structural models shown in Figure 5..$^{22,27} \operatorname{Ir}(\text { chpy })_{3}$ clearly has an aromatic and an aliphatic side, while for $\operatorname{Ir}(\text { piq })_{3}$ the difference is

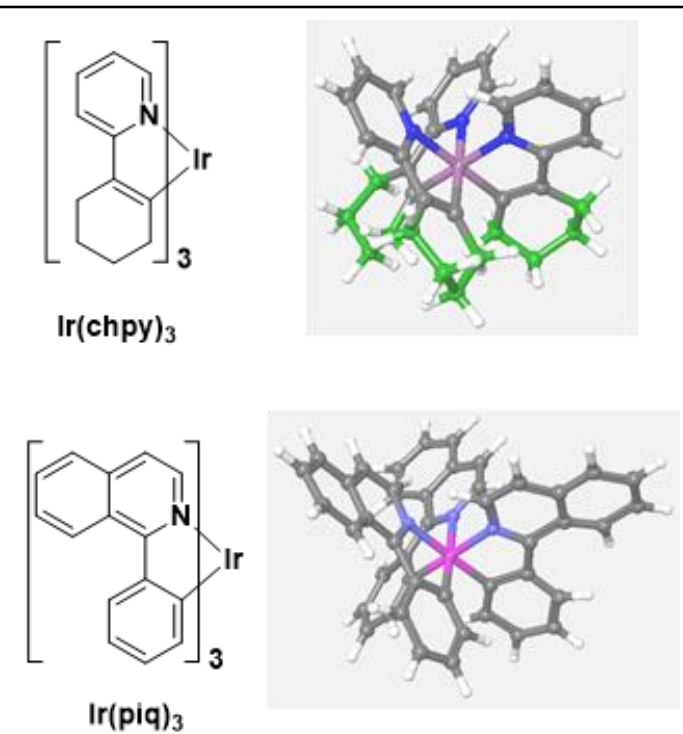

Figure 5. Oriented Homoleptic Phosphors Molecular models of two facial- $\operatorname{Ir}\left(\mathrm{C}^{\wedge} \mathrm{N}\right)_{3}$ complexes that align in a CBP matrix. The aliphatic carbons of the chpy ligand have been colored green. more subtle. If this anisotropy orients the molecule by our proposed mechanism, we would expect the molecular $\mathrm{C}_{3}$ axis of these molecules to orient perpendicular to the surface, and the measured $\Theta$ value would correspond to TDV angles of $\delta \approx 10^{\circ}$ (Figure 6), well within the anticipated range for these $\mathrm{C}^{\wedge} \mathrm{N}$ ligands.

Our work demonstrates the optimal design principles for Ir-based dopants to exploit the benefits of dopant orientation in OLEDs. For $\left(\mathrm{C}^{\wedge} \mathrm{N}\right)_{2} \operatorname{Ir}\left(\mathrm{O}^{\wedge} \mathrm{O}\right)$ it would be advantageous to shift

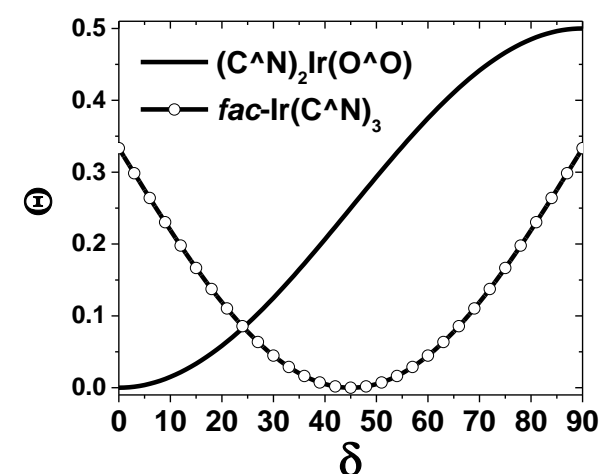

Figure 6. Ideal Molecular Orientation Plot of $\delta$ vs $\Theta$ for $\left(\mathrm{C}^{\wedge} \mathrm{N}\right)_{2} \operatorname{Ir}\left(\mathrm{O}^{\wedge} \mathrm{O}\right)$ (black) and fac$\operatorname{Ir}\left(\mathrm{C}^{\wedge} \mathrm{N}\right)_{3}$ (red) complexes with their respective $\mathrm{C}_{2}$ and $\mathrm{C}_{3}$ axes oriented perpendicular to the substrate. the direction of the TDV toward the $\mathrm{Ir}-\mathrm{N}$ bond axis, ideally to $\delta=0^{\circ}$ (Figure 6). Note that any net orientation between with $\varphi=0-20^{\circ}$ gives values of $\Theta<0.1$ when $\delta=0^{\circ}$ (Figure 4(a)). Such a broad spread of orientations is well within the range seen for the compounds reported here. The outcoupling efficiency of an OLED with $\Theta=0.1$ would increase by roughly a factor of 1.5 as compared to the isotropic case. ${ }^{23}$ Alternatively, if one could align the dopants more uniformly with their $\mathrm{C}_{2}$ axis 
perpendicular to the substrate ( $\varepsilon=45$ or $225^{\circ}$ and $\left.\varphi=0\right), \Theta$ of $\leq 0.1$ could be achieved with $\delta$ values as high as $25^{\circ}$ (Figure 6). $\left(\mathrm{C}^{\wedge} \mathrm{N}\right)_{2} \operatorname{Ir}(\mathrm{acac})$ complexes limit the operational stability of OLEDs, due largely to the instability of the acac ligand. Heteroleptic Ir complexes, i.e. $\left(\mathrm{C}^{\wedge} \mathrm{N}\right)_{2} \operatorname{Ir}\left(\mathrm{C}^{\wedge} \mathrm{N}^{\prime}\right)$, however, do not suffer from poor device stability. The mechanism described here, invoking structural anisotropy of the dopant to promote alignment, is equally applicable to heteroleptic complexes with aliphatic groups are incorporated into either $\mathrm{C}^{\wedge} \mathrm{N}$ or $\mathrm{C}^{\wedge} \mathrm{N}^{\prime}$. Figure 6 also shows that related $f a c-\operatorname{Ir}\left(\mathrm{C}^{\wedge} \mathrm{N}\right)_{3}$ complexes with $\delta$ values between $20^{\circ}$ and $70^{\circ}$, if aligned with their $\mathrm{C}_{3}$ axes perpendicular to the substrate, are also capable of generating highly anisotropic emission. Notably, $\delta$ values between $40^{\circ}$ to $50^{\circ}$ will give $\Theta<0.01$ over a fairly broad range of $\varepsilon$ and $\varphi$ values.

\section{Conclusion}

We conclude that the presence of the acac group is responsible for the commonly measured value of $\Theta \cong 0.2$ for a large variety of $\left(\mathrm{C}^{\wedge} \mathrm{N}\right)_{2} \operatorname{Ir}(\mathrm{acac})$ species. The acac ligand forms an aliphatic region on the surface of the otherwise aromatic Ir complex. We hypothesize that interaction of this chemically anisotropic species at the boundary created between the vacuum and the organic surface during deposition is responsible for the observed net alignment of the TDVs of the dopants, wherein the phosphor's $C_{2}$ axis is largely perpendicular to the plane of the substrate. This proposed mechanism for alignment is consistent with the $\Theta$ value being unaffected by aggregation of the dopant. A similar mechanism for dopant alignment can be used to explain the low $\Theta$ values reported for facial- $\operatorname{Ir}\left(\mathrm{C}^{\wedge} \mathrm{N}\right)_{3}$ complexes where the $\mathrm{C}^{\wedge} \mathrm{N}$ ligand itself gives rise to significant chemical anisotropy of the dopant molecule, i.e. $\operatorname{Ir}(\text { chpy })_{3}$ and $\operatorname{Ir}(\text { piq })_{3} .{ }^{27}$

Future work will explore the impact of the introduction of aliphatic character to different ligands. We will also explore the impact of host materials and their physical properties on the alignment behavior of the dopants in films.

\section{Electronic Supporting Information}

Table of literature values, ${ }^{1} \mathrm{H}$ and ${ }^{13} \mathrm{C}$ NMR spectra, photoluminescence emission spectra, photophysical data, electrochemistry of bppo, (bppo $)_{2} \operatorname{Ir}(\mathrm{acac}),(\mathrm{ppy})_{2} \operatorname{Ir}(\mathrm{bppo}),(\mathrm{bppo})_{2} \operatorname{Ir}(\mathrm{ppy})$, 
table of calculated interaction potentials, derivation of mathematical formulae, full $360^{\circ}$ anisotropy factor plots, AFM images and examples.

\section{Table of Contents Graphic}
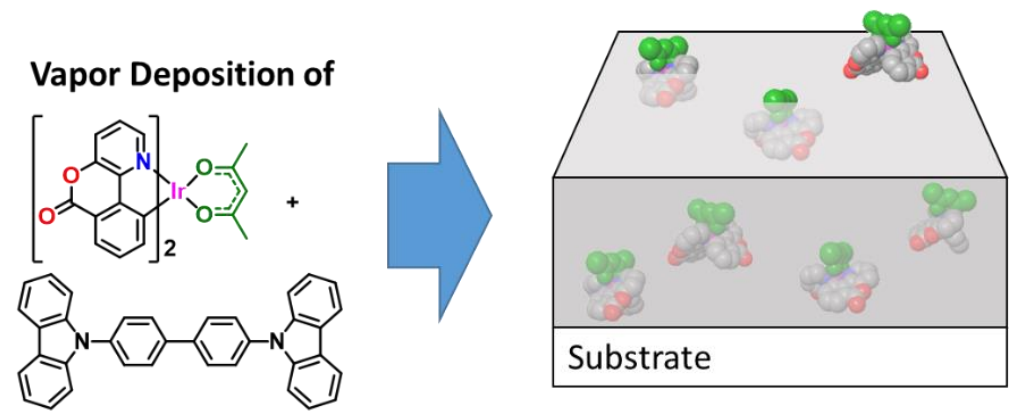

Heteroleptic $\left(\mathrm{C}^{\wedge} \mathrm{N}\right)_{2} \operatorname{Ir}($ acac $)$ phosphors orient within a growing $\mathrm{CBP}$ thin film. 
References

1 Scharber, M. C. et al. Design Rules for Donors in Bulk-Heterojunction Solar CellsTowards 10\% Energy-Conversion Efficiency. Advanced Materials 18, 789-794, doi:10.1002/adma.200501717 (2006).

2 Jurow, M. J. et al. Controlling morphology and molecular packing of alkane substituted phthalocyanine blend bulk heterojunction solar cells. Journal of Materials Chemistry A $\mathbf{1}$, 1557-1565, doi:10.1039/c2ta00415a (2013).

3 Tsao, H. N. et al. The Influence of Morphology on High-Performance Polymer Field-Effect Transistors. Advanced Materials 21, 209-212, doi:10.1002/adma.200802032 (2009).

4 Yokoyama, D. Molecular orientation in small-molecule organic light-emitting diodes. Journal of Materials Chemistry 21, 19187-19202, doi:10.1039/c1jm13417e (2011).

5 Namdas, E. B., Ruseckas, A., Samuel, I. D. W., Lo, S.-C. \& Burn, P. L. Photophysics of Fac-Tris(2-Phenylpyridine) Iridium(III) Cored Electroluminescent Dendrimers in Solution and Films. The Journal of Physical Chemistry B 108, 1570-1577, doi:10.1021/jp035664k (2004).

6 Baldo, M. A. et al. Highly efficient phosphorescent emission from organic electroluminescent devices. Nature 395, 151-154 (1998).

7 Baldo, M. A., Lamansky, S., Burrows, P. E., Thompson, M. E. \& Forrest, S. R. Very highefficiency green organic light-emitting devices based on electrophosphorescence. Applied Physics Letters 75, 4-6, doi:http://dx.doi.org/10.1063/1.124258 (1999).

8 Mladenovski, S., Neyts, K., Pavicic, D., Werner, A. \& Rothe, C. Exceptionally efficient organic light emitting devices using high refractive index substrates. Opt. Express 17, 7562-7570, doi:10.1364/oe.17.007562 (2009).

9 Reineke, S. et al. White organic light-emitting diodes with fluorescent tube efficiency. Nature $\quad 459,234-238$, doi:http://www.nature.com/nature/journal/v459/n7244/suppinfo/nature08003_S1.html (2009).

10 Brütting, W., Frischeisen, J., Schmidt, T. D., Scholz, B. J. \& Mayr, C. Device efficiency of organic light-emitting diodes: Progress by improved light outcoupling. physica status solidi (a) 210, 44-65, doi:10.1002/pssa.201228320 (2013).

11 Schmidt, T. D. et al. Evidence for non-isotropic emitter orientation in a red phosphorescent organic light-emitting diode and its implications for determining the emitter's radiative quantum efficiency. Applied Physics Letters 99, 163302-, doi:http://dx.doi.org/10.1063/1.3653475 (2011). 
12 Forrest, S. R. The path to ubiquitous and low-cost organic electronic appliances on plastic. Nature 428, 911-918 (2004).

13 Sasabe, H. \& Kido, J. Development of high performance OLEDs for general lighting. Journal of Materials Chemistry C 1, 1699-1707, doi:10.1039/c2tc00584k (2013).

14 Sasabe, H. \& Kido, J. Recent Progress in Phosphorescent Organic Light-Emitting Devices. European Journal of Organic Chemistry 2013, 7653-7663, doi:10.1002/ejoc.201300544 (2013).

15 Mayr, C., Schmidt, T. D. \& Brütting, W. High-efficiency fluorescent organic light-emitting diodes enabled by triplet-triplet annihilation and horizontal emitter orientation. Applied Physics Letters 105, 183304, doi:http://dx.doi.org/10.1063/1.4901341 (2014).

16 Liehm, P. et al. Comparing the emissive dipole orientation of two similar phosphorescent green emitter molecules in highly efficient organic light-emitting diodes. Applied Physics Letters 101, 253304 -, doi:http://dx.doi.org/10.1063/1.4773188 (2012).

17 Mayr, C. \& Brutting, W. Control of Molecular Dye Orientation in Organic Luminescent Films by the Glass Transition Temperature of the Host Material. Chemistry of Materials 27, 2759-2762, doi: 10.1021/acs.chemmater.5b00062 (2015).

18 Flämmich, M. et al. Oriented phosphorescent emitters boost OLED efficiency. Organic Electronics 12, 1663-1668, doi:10.1016/j.orgel.2011.06.011 (2011).

19 Helander, M. G. et al. Chlorinated Indium Tin Oxide Electrodes with High Work Function for Organic Device Compatibility. Science 332, 944-947, doi:10.1126/science.1202992 (2011).

20 Lamansky, S. et al. Highly Phosphorescent Bis-Cyclometalated Iridium Complexes: Synthesis, Photophysical Characterization, and Use in Organic Light Emitting Diodes. Journal of the American Chemical Society 123, 4304-4312, doi:10.1021/ja003693s (2001).

21 Lassiter, B. E. et al. Organic photovoltaics incorporating electron conducting exciton blocking layers. Applied Physics Letters 98, 243307 , doi:http://dx.doi.org/10.1063/1.3598426 (2011).

22 Kim, K.-H. et al. Phosphorescent dye-based supramolecules for high-efficiency organic light-emitting diodes. Nat Commun 5, 4769 doi:10.1038/ncomms5769 (2014).

23 Kim, K.-H., Moon, C.-K., Lee, J.-H., Kim, S.-Y. \& Kim, J.-J. Highly Efficient Organic Light-Emitting Diodes with Phosphorescent Emitters Having High Quantum Yield and Horizontal Orientation of Transition Dipole Moments. Advanced Materials 26, 3844-3847, doi:10.1002/adma.201305733 (2014). 
24 Kim, S.-Y. et al. Organic Light-Emitting Diodes with 30\% External Quantum Efficiency Based on a Horizontally Oriented Emitter. Advanced Functional Materials 23, 3896-3900, doi:10.1002/adfm.201300104 (2013).

25 Lee, J.-H. et al. Finely Tuned Blue Iridium Complexes with Varying Horizontal Emission Dipole Ratios and Quantum Yields for Phosphorescent Organic Light-Emitting Diodes. Advanced Optical Materials 3, 211-220, doi:10.1002/adom.201400350 (2014).

26 Mayr, C. \& Brütting, W. Control of Molecular Dye Orientation in Organic Luminescent Films by the Glass Transition Temperature of the Host Material. Chemistry of Materials 27, 2759 - 2762, doi:10.1021/acs.chemmater.5b00062 (2015).

27 Graf, A. et al. Correlating the transition dipole moment orientation of phosphorescent emitter molecules in OLEDs with basic material properties. Journal of Materials Chemistry C 2, 10298-10304, doi:10.1039/c4tc00997e (2014).

28 Reineke, S., Rosenow, T. C., Lüssem, B. \& Leo, K. Improved High-Brightness Efficiency of Phosphorescent Organic LEDs Comprising Emitter Molecules with Small Permanent Dipole Moments. Advanced Materials 22, 3189-3193, doi:10.1002/adma.201000529 (2010).

29 Reineke, S., Schwartz, G., Walzer, K., Falke, M. \& Leo, K. Highly phosphorescent organic mixed films: The effect of aggregation on triplet-triplet annihilation. Applied Physics Letters 94, 163305, doi:http://dx.doi.org/10.1063/1.3123815 (2009).

30 Kim, K.-H. et al. Controlling Emitting Dipole Orientation with Methyl Substituents on Main Ligand of Iridium Complexes for Highly Efficient Phosphorescent Organic LightEmitting Diodes. Advanced Optical Materials 3, doi:10.1002/adom.201500141 (2015).

31 Moon, C.-K., Kim, K.-H., Lee, J. W. \& Kim, J.-J. Influence of host molecules on emitting dipole orientation of phosphorescent iridium complexes. Chemistry of Materials 27, 27672769, doi:10.1021/acs.chemmater.5b00469 (2015).

32 Ren, X. et al. Coumarin-Based, Electron-Trapping Iridium Complexes as Highly Efficient and Stable Phosphorescent Emitters for Organic Light-Emitting Diodes. Inorganic Chemistry 49, 1301-1303, doi:10.1021/ic9022097 (2010).

33 Jaguar v. version 8.4r17 (Schrödinger, LLC, New York, 2014).

34 Becke, A. D. Density-functional thermochemistry. III. The role of exact exchange. The Journal of Chemical Physics 98, 5648-5652, doi:http://dx.doi.org/10.1063/1.464913 (1993).

35 Hay, P. J. \& Wadt, W. R. Ab initio effective core potentials for molecular calculations. Potentials for the transition metal atoms Sc to Hg. The Journal of Chemical Physics 82, 270-283, doi:http://dx.doi.org/10.1063/1.448799 (1985). 
36 Stephens, P. J., Devlin, F. J., Chabalowski, C. F. \& Frisch, M. J. Ab Initio Calculation of Vibrational Absorption and Circular Dichroism Spectra Using Density Functional Force Fields. The Journal of Physical Chemistry 98, 11623-11627 (1994).

37 Frischeisen, J., Yokoyama, D., Endo, A., Adachi, C. \& Brütting, W. Increased light outcoupling efficiency in dye-doped small molecule organic light-emitting diodes with horizontally oriented emitters. Organic Electronics 12, 809-817, doi:http://dx.doi.org/10.1016/j.orgel.2011.02.005 (2011).

38 Frischeisen, J., Yokoyama, D., Adachi, C. \& Brütting, W. Determination of molecular dipole orientation in doped fluorescent organic thin films by photoluminescence $\begin{array}{llll}\text { measurements. } \quad \text { Applied } \quad \text { Physics } & \text { Letters }\end{array}$ doi:http://dx.doi.org/10.1063/1.3309705 (2010).

39 Mayr, C. et al. Efficiency Enhancement of Organic Light-Emitting Diodes Incorporating a Highly Oriented Thermally Activated Delayed Fluorescence Emitter. Advanced Functional Materials 24, 5232-5239, doi:10.1002/adfm.201400495 (2014).

40 Weber, W. H. \& Eagen, C. F. Energy transfer from an excited dye molecule to the surface plasmons of an adjacent metal. Opt. Lett. 4, 236-238, doi:10.1364/OL.4.000236 (1979).

41 Kawamura, Y., Brooks, J., Brown, J. J., Sasabe, H. \& Adachi, C. Intermolecular Interaction and a Concentration-Quenching Mechanism of Phosphorescent Ir(III) Complexes in a Solid Film. Physical Review Letters 96, 017404, doi:10.1103/PhysRevLett.96.017404 (2006).

42 Chi, Y. \& Chou, P.-T. Transition-metal phosphors with cyclometalating ligands: fundamentals and applications. Chemical Society Reviews 39, 638-655, doi:10.1039/b916237b (2010).

43 Vanhelmont, F. W. M., Strouse, G. F., Güdel, H. U., Stückl, A. C. \& Schmalle, H. W. Synthesis, Crystal Structure, High-Resolution Optical Spectroscopy, and Extended Hückel Calculations on Cyclometalated $[\operatorname{Re}(\mathrm{CO}) 4(\mathrm{ppy})]$ (ppy = 2-Phenylpyridine). The Journal of Physical Chemistry A 101, 2946-2952, doi:10.1021/jp9628161 (1997).

44 Dalal, S. S., Walters, D. M., Lyubimov, I., de Pablo, J. J. \& Ediger, M. D. Tunable molecular orientation and elevated thermal stability of vapor-deposited organic semiconductors. Proceedings of the National Academy of Sciences 112, 4227-4232, doi:10.1073/pnas.1421042112 (2015).

45 Kearns, K. L. et al. Molecular orientation, thermal behavior and density of electron and hole transport layers and the implication on device performance for OLEDs. Proceedings of the SPIE 9183, 91830F (2014).

46 Tsai, M. H. et al. 3-(9-Carbazolyl)carbazoles and 3,6-Di(9-carbazolyl)carbazoles as Effective Host Materials for Efficient Blue Organic Electrophosphorescence. Advanced Materials 19, 862-866, doi:10.1002/adma.200600822 (2007). 
47 Dalal, S. S., Fakhraai, Z. \& Ediger, M. D. High-Throughput Ellipsometric Characterization of Vapor-Deposited Indomethacin Glasses. The Journal of Physical Chemistry B 117, 15415-15425, doi:10.1021/jp405005n (2013).

48 Brian, C. W. \& Yu, L. Surface Self-Diffusion of Organic Glasses. The Journal of Physical Chemistry A 117, 13303-13309, doi:10.1021/jp404944s (2013).

49 Zhu, L. et al. Surface Self-Diffusion of an Organic Glass. Physical Review Letters 106, 256103 (2011).

50 Xing, X. et al. Essential Differences of Organic Films at the Molecular Level via Vacuum Deposition and Solution Processes for Organic Light-Emitting Diodes. The Journal of Physical Chemistry C 117, 25405-25408, doi:10.1021/jp410547w (2013).

\section{Funding}

The research described here was carried out with the support of the Universal Display Corporation, The Humboldt Foundation, Bavaria California Technology Center (BaCaTeC) and Deutsche Forschungsgemeinschaft (DFG Br 1728/16-1). C.M. acknowledges financial support by Bayerische Forschungsstiftung. One of the authors (M.E.T.) has a financial interest in the Universal Display Corporation.

\section{Author Contributions}

M.J.J. prepared materials and samples, designed experiments and prepared manuscript; C.M. measured molecular orientation; T.D.S. designed and prepared mathematical models; T.L. designed and prepared mathematical models; P.I.D., W.B. and M.E.T. designed and assisted with experiments and manuscript. Correspondence may be addressed to Prof. Mark E. Thompson (met@usc.edu). 


\section{Methods}

Starting materials were purchased from Sigma Aldrich and used without further purification. CBP was obtained from Universal Display Corporation. Materials were purified by gradient sublimation before use. Chloro-bridged bis-cyclometalated iridium complexes of the formula $\left[\operatorname{Ir}\left(\mathrm{C}^{\wedge} \mathrm{N}\right)_{2} \mathrm{Cl}\right]_{2}$ were synthesized according to literature procedures. ${ }^{51} 6 \mathrm{H}-$ [2]benzopyrano[4,3-b ]pyridin-6-one (bppo) was synthesized according to literature procedure. ${ }^{52}$

Iridium(III) Bis(benzopyranopyridinone)(acetylacetonate) ((bppo $)_{2} \operatorname{Ir}($ acac)): Chlorobridged bppo dimer $(1.4 \mathrm{mmol})$, silver triflate $(3.08 \mathrm{mmol})$, bppo ligand $(3.1 \mathrm{mmol})$ and potassium carbonate $(13.9 \mathrm{mmol})$ were added to a round-bottom flask under nitrogen atmosphere. The flask was charged with dry dichloroethane and stirred at reflux overnight. The solvent was removed under vacuum and the mixture was dissolved in $\mathrm{CH}_{2} \mathrm{Cl}_{2}$. The mixture was then filtered to remove silver chloride and chromatographed in $60: 40 \mathrm{CH}_{2} \mathrm{Cl}_{2}$ :ethyl acetate (v/v). The collected fraction was precipitated from $\mathrm{CH}_{2} \mathrm{Cl}_{2}$ and hexanes to yield $280 \mathrm{mg}$ pure (bppo) ${ }_{2} \operatorname{Ir}(\mathrm{acac})(51 \%) .{ }^{1} \mathrm{H} \mathrm{NMR}$ $\left(\mathrm{CDCl}_{3}\right): 1.86$ (s, Me-acac, 6H), 5.32 (s, acac, 1H), 6.60 (dd, 2H), 7.04 (t, 2H), 7.42 (q, 2H), 7.66 (qd, $2 \mathrm{H}), 8.35$ (dd, 2H). Electrospray ionization mass spectrum (ESI-MS): $\mathrm{C}_{29} \mathrm{H}_{19} \mathrm{IrN}_{2} \mathrm{O}_{6} \mathrm{M} / \mathrm{Z}$ calculated 684.0872, found: 684.0851

Iridium(III) Bis(2-phenylpyridinate)(benzopyranopyridinone) $\quad\left((\text { ppy })_{2} \operatorname{Ir}(\right.$ bppo $)$ ) and Iridium(III) Bis(benzopyranopyridinone)( 2-phenylpyridinate) ((bppo) ${ }_{2} \operatorname{Ir}($ ppy)): Synthesis modified from previous report. ${ }^{32}$ Chloro-bridged ppy dimer $(0.4 \mathrm{mmol})$, silver triflate $(0.88 \mathrm{mmol})$ and potassium carbonate $(20 \mathrm{mmol})$ were added to a round-bottom flask under nitrogen atmosphere. The flask was charged with dry 1,2 o-dichlorobenzene. The reaction mixture was stirred at reflux overnight. The solvent was removed under vacuum and residue was dissolved in $\mathrm{CH}_{2} \mathrm{Cl}_{2}$. The mixture was filtered to remove silver chloride and chromatographed in $\mathrm{CH}_{2} \mathrm{Cl}_{2}$ to yield $450 \mathrm{mg}$ (ppy) ${ }_{2} \operatorname{Ir}(\text { bppo) }(23 \%) \text { and } 325 \mathrm{mg} \text { (bppo })_{2} \operatorname{Ir}$ (ppy) (31\%). (bppo) $)_{2} \operatorname{Ir}$ (ppy): electrospray ionization mass spectrum (ESI-MS) of $\mathrm{C}_{35} \mathrm{H}_{20} \mathrm{IrN}_{3} \mathrm{O}_{4}$, calculated M/Z: 739.1083; found: $\left(\mathrm{MH}^{+}\right)$ 740.1144. ${ }^{1} \mathrm{H}$ NMR $\left(\mathrm{CDCL}_{3}\right): 7.95(\mathrm{~d}, 1 \mathrm{H}), 7.79(\mathrm{~m}, 1 \mathrm{H}), 7.76(\mathrm{~d}, 1 \mathrm{H}), 7.68(\mathrm{~m}, 3 \mathrm{H}), 7.59(\mathrm{~m}$, 1H), $7.57(\mathrm{~m}, 1 \mathrm{H}), 7.50(\mathrm{dd}, 1 \mathrm{H}), 7.46(\mathrm{dd}, 1 \mathrm{H}), 7.21(\mathrm{~d}, 1 \mathrm{H}), 7.20(\mathrm{~m}, 1 \mathrm{H}), 7.17(\mathrm{~m}, 3 \mathrm{H}), 7.03$ (dd, 1H), 6.97 (m, 2H), 6.87 (td, 1H), 6.74 (dd, 1H).

\section{Optical spectra}

Photoluminescence spectra were measured using a QuantaMaster Photon Technology International phosphorescence/fluorescence spectrofluorometer. Luminescent lifetimes were measured by time-correlated single-photon counting using an IBH Fluorocube instrument equipped with an LED excitation source. Quantum yield measurements were carried out using a Hamamatsu C9920 system equipped with a xenon lamp, calibrated integrating sphere and model C10027 photonic multi-channel analyzer (PMA). UV-vis spectra were recorded on a HewlettPackard 4853 diode array spectrometer.

\section{$\underline{\text { Thin film deposition }}$}

Films were made in an Angstrom Engineering EvoVac 800 VTE deposition system attached to a glove box and Inficon SQS-242 deposition software was used to control deposited material thicknesses using a $6 \mathrm{MHz}$ Inficon quartz monitor gold coated crystal sensor. All films deposited in the VTE were performed at pressures $\leq 4 \times 10^{-4} \mathrm{~Pa}$ and with deposition rates less than

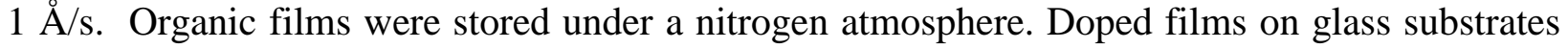


for orientation measurements were fabricated at pressures $\leq 5 \times 10^{-5} \mathrm{~Pa}$ with deposition rates of ca. $1.5 \AA / s$ for CBP and various dopant concentrations (v/v). Films were encapsulated with a glass cover in nitrogen atmosphere to prevent photodegeneration upon PL excitation during orientation measurements. To determine the molecular orientation in doped films, angular-dependent photoluminescence (PL) measurements have been performed. The sample was attached to a fused silica half cylinder prism by index matching liquid and the emission angle was changed using a rotation stage. Spectra were recorded using a fibre optical spectrometer (SMS-500, Sphere Optics) and a polarizing filter to distinguish between p- and s-polarized light. The excitation of the samples was performed with a $375 \mathrm{~nm} \mathrm{cw}$ laser diode with a fixed excitation angle of $45^{\circ}$. The degree of orientation of the optical transition dipole moments of the emitter molecules was determined from numerical simulation reported previously. ${ }^{37}$

Spin Coating

Films were spin cast from chloroform solutions. We dissolved $1 \mathrm{mg}$ of each organic compound in $1 \mathrm{ml}$ chloroform. We then prepared a mixture of both solutions with $4.6 \mathrm{ml}$ NPD / chloroform and $0.4 \mathrm{ml} \operatorname{Ir}(\mathrm{MDQ})_{2}$ (acac) / chloroform resulting in a doping concentration of $8 \%$ $\operatorname{Ir}(\mathrm{MDQ})_{2}(\mathrm{acac}): \mathrm{NPD}$. Variable angle spectroscopic ellipsometry was performed (Si-substrate used) to determine thickness and the optical constants of the films after spin coating and drying for $1 \mathrm{~h}$ at room temperature. The thickness of the films was additionally checked by the fitting procedure of the angular dependent photoluminescence emission spectra ( $\mathrm{p}$-pol for the orientation and s-pol for the actual thickness).

Theoretical calculations

Calculations were performed using Jaguar 8.4 (release 17) software package on the Schrodinger Material Science Suite (v2014-2). ${ }^{33}$ Gas-phase geometry optimization was calculated using B3LYP functional with the LACVP** basis set as implemented in Jaguar. ${ }^{34-36}$

\section{Electrochemistry}

(bppo) $)_{2} \operatorname{Ir}($ acac) shows reversible reductions at $-2.06 \mathrm{~V}$ and $-2.29 \mathrm{~V}$ and a reversible oxidation at $0.69 \mathrm{~V}$ (vs. $\mathrm{Fc}^{+} / \mathrm{Fc}$ ) by cyclic voltammetry. (bppo) ${ }_{2} \operatorname{Ir}(\mathrm{ppy})$ shows reversible reductions at $-2.12 \mathrm{~V}$ and $-2.31 \mathrm{~V}$ and a reversible oxidation at $0.63 \mathrm{~V}$ (vs. $\left.\mathrm{Fc}^{+} / \mathrm{Fc}\right)$. (ppy) $)_{2} \operatorname{Ir}(\mathrm{bppo})$ shows a fully reversible reduction at $-2.19 \mathrm{~V}$ and a quasi-reversible reduction at $-2.77 \mathrm{~V}$ with a reversible oxidation at $0.48 \mathrm{~V}$ (vs. $\mathrm{Fc}^{+} / \mathrm{Fc}$ ). The reversible oxidations are assigned to a metal centered oxidation and the observed reductions are to a ligand centered process. The more positive oxidations and more negative reductions relative to classic phosphors is proposed to be a consequence of the introduction of the extremely electron withdrawing coumarin ligands. These strongly $\pi$ electron deficient ligands depresses the HOMO energy but do not change the LUMO as long as the emissive state remains localized on the bppo ligand. Electrochemistry of $\operatorname{Ir}(\mathrm{ppy})_{2}$ (bppo) has been reported previously. ${ }^{32}$

$\underline{\text { Transition Dipole Moment, Molecular Orientation, and } \Theta \text { Value Relationships }}$

For a single emitting molecule containing only one possible TDV $\overrightarrow{\mathrm{p}}=\left(\mathrm{p}_{\mathrm{x}}, \mathrm{p}_{\mathrm{y}}, \mathrm{p}_{\mathrm{z}}\right), \Theta$ is given by: $\Theta=p_{z}^{2} /\left(p_{x}^{2}+p_{y}^{2}+p_{z}^{2}\right)$. In molecules containing $n$ different TDVs, or an ensemble of $n$ differently oriented molecules, each of these TDVs must be taken into account. As an excited state is only related to one of them, each TDV must be calculated separately with respect to the contributing fraction $a_{i} ; \sum_{i=1}^{n} a_{i}=1$. Thus the resulting $\Theta$ can be calculated as in Equation 1, where $\vec{p}_{i}$ denotes the $\mathrm{i}$-th TDV and $p_{z, i}$ the corresponding component perpendicular to the surface. 


$$
\theta=\frac{\sum_{i=1}^{n} a_{i} p_{z, i}^{2}}{\sum_{i=1}^{n} a_{i} \vec{p}_{i}^{2}}
$$

To explore the relationship between the anisotropy factor $\Theta$ for different orientations of a heteroleptic Ir-complex comprising one acac-group and two other identical ligands $\operatorname{Ir}(\mathrm{L})_{2}(\mathrm{acac})$ we have designed a coordinate system around an idealized molecule, depicted in Figure 4a.

The biggest influence on the orientation of the molecule is achieved by the acac-group. Therefore, we selected two individual angles to control the orientation of the molecule, and one to account for variations in the angle of the transition dipole moment (TDM). We define the angle $\mathrm{N}$-Ir-TDV as $\delta$, rotation around the $\mathrm{x}$-axis as $\varepsilon$ and rotation around the $\mathrm{y}$-axis as $\varphi$.

In order to model the rotation of the molecule counter-clockwise around the $\mathrm{x}$-axis we use a rotation matrix $\left(R_{x}\right)$

$$
R_{x}=\left(\begin{array}{ccc}
1 & 0 & 0 \\
0 & \cos (\epsilon) & -\sin (\epsilon) \\
0 & \sin (\epsilon) & \cos (\epsilon)
\end{array}\right)
$$

to represent the change in the position of the transition dipole moment of both ligands, using the coordinate system of the starting geometry (Figure $4 \mathrm{a}$ ), denoted as $\vec{L}_{1}$ (x-y-plane) and $\vec{L}_{2}$ (y-zplane):

$$
\begin{aligned}
& \overrightarrow{L_{1}}=\left(\begin{array}{c}
-\cos (\delta) \\
-\sin (\delta) \\
0
\end{array}\right) \\
& \overrightarrow{L_{2}}=\left(\begin{array}{c}
\cos (\delta) \\
0 \\
-\sin (\delta)
\end{array}\right)
\end{aligned}
$$

The rotated TDV ( $\vec{L}_{1}^{*}$ and $\vec{L}_{2}^{*}$ ) values for both ligands are obtained by multiplying the rotation matrix with the initial TDM vector: 


$$
\begin{aligned}
& R_{x} \circ \overrightarrow{L_{1}}={\overrightarrow{L_{1}}}^{*}=\left(\begin{array}{c}
-\cos (\delta) \\
-\sin (\delta) \cos (\epsilon) \\
-\sin (\delta) \sin (\epsilon)
\end{array}\right) \\
& R_{x} \circ \overrightarrow{L_{2}}={\overrightarrow{L_{2}}}^{*}=\left(\begin{array}{c}
\cos (\delta) \\
\sin (\delta) \sin (\epsilon) \\
-\sin (\delta) \cos (\epsilon)
\end{array}\right) .
\end{aligned}
$$

However, as only the squared vectors are of interest to calculate the anisotropy factor, the total $\mathrm{X}-, \mathrm{Y}$ - and Z-components are given by the sum of the individual contributions of the two vectors:

$$
\begin{gathered}
X=[-\cos (\delta)]^{2}+[\cos (\delta)]^{2} \\
Y=[-\sin (\delta) \cos (\epsilon)]^{2}+[\sin (\delta) \sin (\epsilon)]^{2} \\
Z=[-\sin (\delta) \sin (\epsilon)]^{2}+[-\sin (\delta) \cos (\epsilon)]^{2}
\end{gathered}
$$

The anisotropy factor $\Theta$ can then be calculated for arbitrary angles of $\delta$ and $\varepsilon$ using:

$$
\theta=\frac{Z}{X+Y+Z}
$$

In order to make the analysis more extensive, one can think about a second rotation counterclockwise around the $\mathrm{y}$-axis (dentoted with the angle $\varphi$ in the following) after the $\mathrm{x}$-axis rotation. It is critical to note that the order of the rotations matters. The epsilon rotation must be applied first because the axese themselves do not change, but the molecular arrangement (after the first rotation). Analogous to the former rotation matrix, one would achieve the following values for the three individual parameters $\delta, \varepsilon$ and $\varphi$ :

$$
\begin{gathered}
X=[-\cos (\delta) \cos (\phi)-\sin (\delta) \sin (\epsilon) \sin (\phi)]^{2}+[\cos (\delta) \cos (\phi)-\sin (\delta) \cos (\epsilon) \sin (\phi)]^{2} \\
Y=[-\sin (\delta) \cos (\epsilon)]^{2}+[\sin (\delta) \sin (\epsilon)]^{2} \\
Z=[\cos (\delta) \sin (\phi)-\sin (\delta) \sin (\epsilon) \cos (\phi)]^{2}+[-\cos (\delta) \sin (\phi)-\sin (\delta) \cos (\epsilon) \cos (\phi)]^{2} .
\end{gathered}
$$


The same procedure can also be applied to a homoleptic tris-Ir-compound such as e.g. $\operatorname{Ir}(\mathrm{ppy})_{3}$. Here, one has to transform/rotate three different TDMs, one for each ligand. In the case that the three nitrogens are lying in $\mathrm{x}-,(-\mathrm{y})$ - and $\mathrm{z}$-direction, depicted in figure $4 \mathrm{~b}$, and the rotations are again performed around the $\mathrm{x}$ - and the $\mathrm{y}$-axis, the TDM-vectors for deriving $\Theta$ are changing to:

$$
\begin{gathered}
{\overrightarrow{L_{1}}}^{\prime}=\left(\begin{array}{c}
-\sin (\delta) \cos (\phi)-\cos (\delta) \sin (\epsilon) \sin (\phi) \\
-\cos (\delta) \cos (\epsilon) \\
\sin (\delta) \sin (\phi)-\cos (\delta) \sin (\epsilon) \cos (\phi)
\end{array}\right) \\
{\overrightarrow{L_{2}}}^{\prime}=\left(\begin{array}{c}
\cos (\delta) \cos (\phi)-\sin (\delta) \cos (\epsilon) \sin (\phi) \\
\sin (\delta) \sin (\epsilon) \\
-\cos (\delta) \sin (\phi)-\sin (\delta) \cos (\epsilon) \cos (\phi)
\end{array}\right) \\
\overrightarrow{L_{3}^{\prime}}=\left(\begin{array}{c}
\sin (\delta) \sin (\epsilon) \sin (\phi)+\cos (\delta) \cos (\epsilon) \sin (\phi) \\
\sin (\delta) \cos (\epsilon)-\cos (\delta) \sin (\epsilon) \\
\sin (\delta) \sin (\epsilon) \cos (\phi)+\cos (\delta) \cos (\epsilon) \cos (\phi)
\end{array}\right)
\end{gathered}
$$

\section{References}

51 Nonoyama, M. Benzo[h]quinolin-10-yl-N Iridium(III) Complexes. Bulletin of the Chemical Society of Japan 47, 767-768, doi:10.1246/bcsj.47.767 (1974).

52 Zhang, W. \& Pugh, G. Free radical reactions for heterocycle synthesis. Part 6: 2Bromobenzoic acids as building blocks in the construction of nitrogen heterocycles. Tetrahedron 59, 3009-3018, doi:http://dx.doi.org/10.1016/S0040-4020(03)00381-8 (2003). 


\section{Understanding and Predicting the Orientation of Heteroleptic Phosphors in Organic Light- Emitting Materials ESI}

Matthew J. Jurow, ${ }^{1}$ Christian Mayr, ${ }^{2}$ Tobias D. Schmidt,${ }^{2}$ Thomas Lampe, ${ }^{2}$ Peter I. Djurovich, ${ }^{1}$ Wolfgang Brütting, ${ }^{2}$ Mark E. Thompson*1

${ }^{1}$ Department of Chemistry, University of Southern California, Los Angeles, California 90089, United States

${ }^{2}$ Institute of Physics, University of Augsburg 86135, Augsburg, Germany

Table of Literature Data............................................................

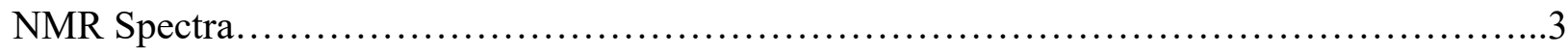

Photophysical Data..............................................................

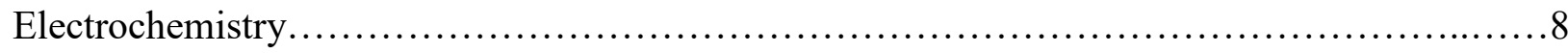

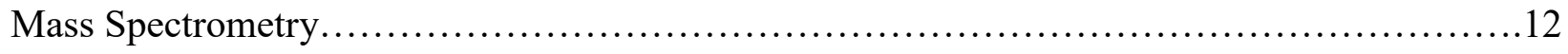

Theoretical Calculations........................................................ 13

Film Emission vs. Concentration .................................................. 14

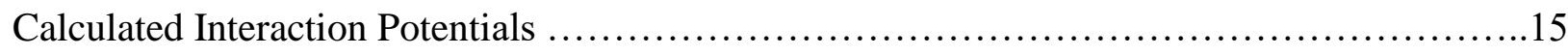

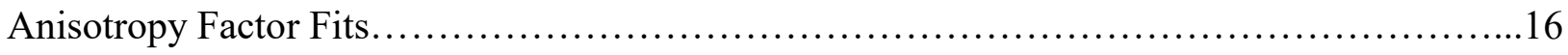

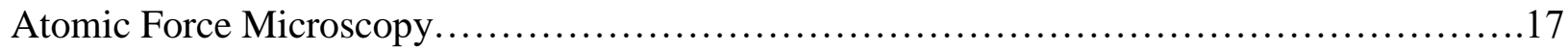

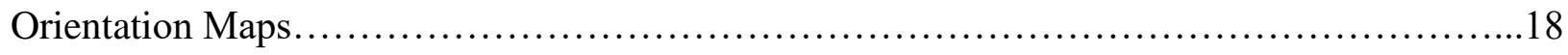

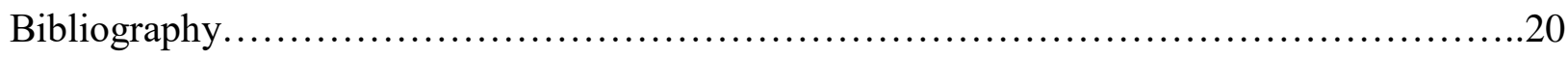


Table of Literature Data

\begin{tabular}{|c|c|c|c|c|}
\hline Phosphor & Host & $\underline{\theta}$ & Dipole (D) & Reference \\
\hline $\operatorname{Ir}(\mathrm{dhfpy})_{2}(\mathrm{acac})$ & NPD & 0.25 & 1.16 & Graf $^{1}$ \\
\hline \multirow[t]{4}{*}{$\operatorname{Ir}(p p y)_{2}(\mathrm{acac})$} & CBP & 0.23 & 1.66 & Graf $^{1}$ \\
\hline & CBP & 0.23 & & Liehm $^{2}$ \\
\hline & TCTA/ B3РYMPM & 0.24 & & $\mathrm{Kim}^{3}$ \\
\hline & TCTA/ BЗРYMPM & 0.23 & & $\mathrm{Kim}^{5}$ \\
\hline $\operatorname{Ir}(\mathrm{ppy})_{2}(\mathrm{tmd})$ & TCTA/ B3РYMPM & 0.22 & 1.72 & $\mathrm{Kim}^{3}$ \\
\hline \multirow[t]{3}{*}{$\operatorname{Ir}(\mathrm{MDQ})_{2}(\mathrm{acac})$} & NPD & 0.24 & 1.75 & Graf $^{1}$ \\
\hline & NPD/ B3PYMPM & 0.20 & & $\mathrm{Kim}^{7}$ \\
\hline & NPD & 0.239 & & Flammich $^{12}$ \\
\hline $\operatorname{lr}(\mathrm{bt})_{2}(\mathrm{acac})$ & BPhen & 0.22 & 1.76 & Graf $^{1}$ \\
\hline $\operatorname{Ir}(\mathrm{chpy})_{3}$ & NPD & 0.23 & 2.02 & Graf $^{1}$ \\
\hline $\operatorname{Ir}(\mathrm{mphmq})_{2}(\mathrm{tmd})$ & NPD/ B3PYMPM & 0.18 & 2.42 & $\mathrm{Kim}^{7}$ \\
\hline $\operatorname{Ir}(\mathrm{mphq})_{2}(\mathrm{acac})$ & NPD/ B3PYMPM & 0.23 & 2.52 & $\mathrm{Kim}^{7}$ \\
\hline $\operatorname{Ir}(p h q)_{3}$ & NPD/ B3PYMPM & 0.30 & 4.63 & $\mathrm{Kim}^{7}$ \\
\hline $\operatorname{lr}(p i q)_{3}$ & NPD & 0.22 & 5.20 & Graf $^{1}$ \\
\hline $\operatorname{Ir}(\mathrm{bppo})_{2}(\mathrm{acac})$ & CBP & 0.219 & 6.18 & This work \\
\hline \multirow[t]{3}{*}{$\operatorname{Ir}(p p y)_{3}$} & CBP & 0.31 & 6.40 & Graf $^{1}$ \\
\hline & CBP & 0.33 & & Liehm $^{2}$ \\
\hline & TCTA/ В3РYMPM & 0.33 & & $\mathrm{Kim}^{3}$ \\
\hline $\operatorname{Ir}(\mathrm{ppy})_{2}(\mathrm{bppo})$ & CBP & 0.32 & 8.25 & This work \\
\hline $\operatorname{Ir}(\mathrm{tBuCN}-\mathrm{F})_{2}(\mathrm{acac})$ & $\mathrm{pBCb} 2 \mathrm{Cz} / \mathrm{TSPO} 1$ & 0.23 & 10.59 & Lee $^{13}$ \\
\hline $\operatorname{Ir}(\mathrm{EtOCN}-\mathrm{F})_{2}$ (acac) & pBCb2Cz/ TSPO1 & 0.22 & 11.65 & Lee $^{13}$ \\
\hline
\end{tabular}

Table S1. Reported dopant/host systems and their reported $\Theta$ values. 
$\underline{\text { NMR Spectra }}$

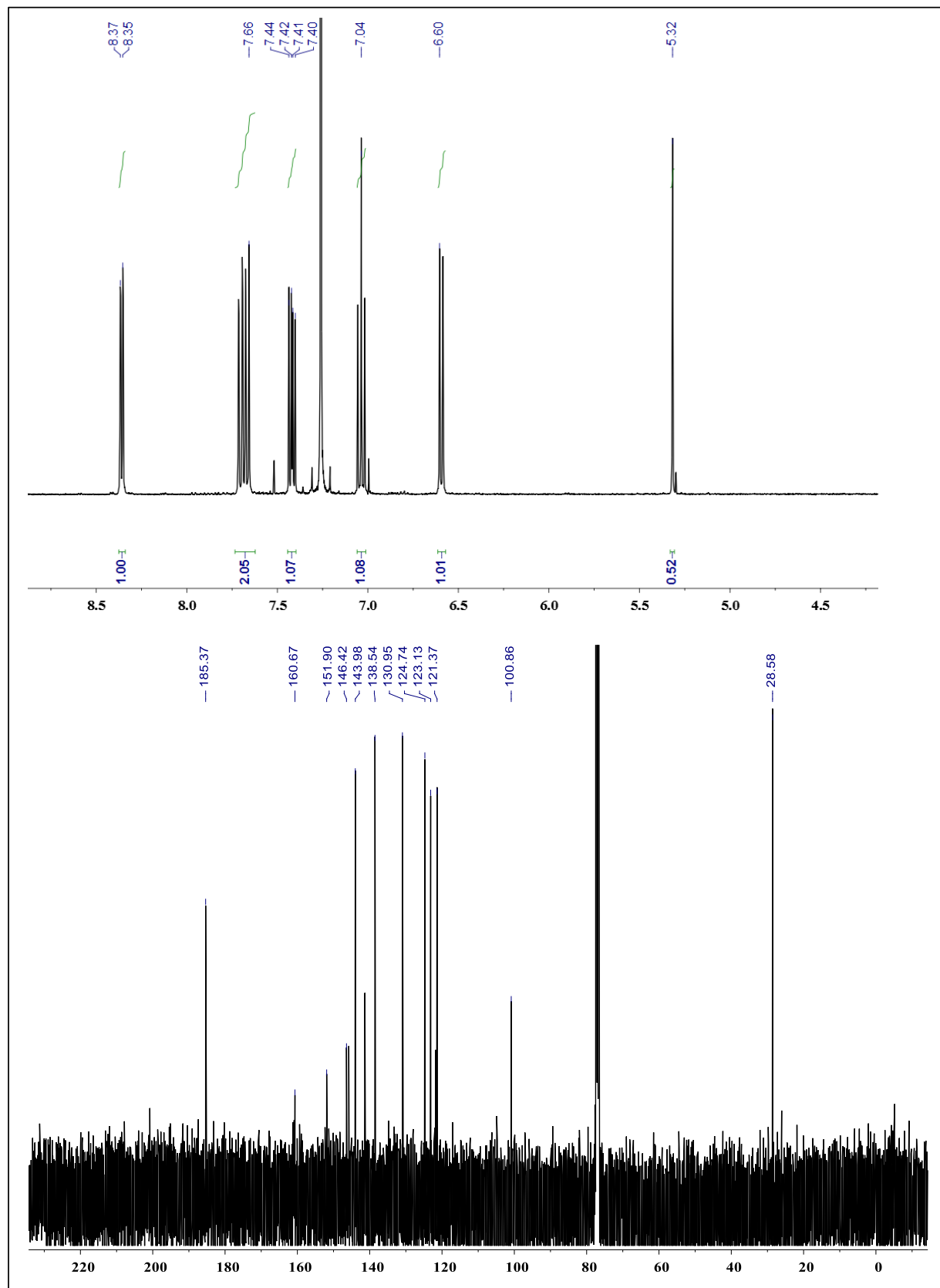

Figure S1. ${ }^{1} \mathrm{H}$ (top) and ${ }^{13} \mathrm{C}$ (bottom) NMR spectra of $\operatorname{Ir}($ bppo) 2 (acac) in $\mathrm{CDCL}_{3}$. 


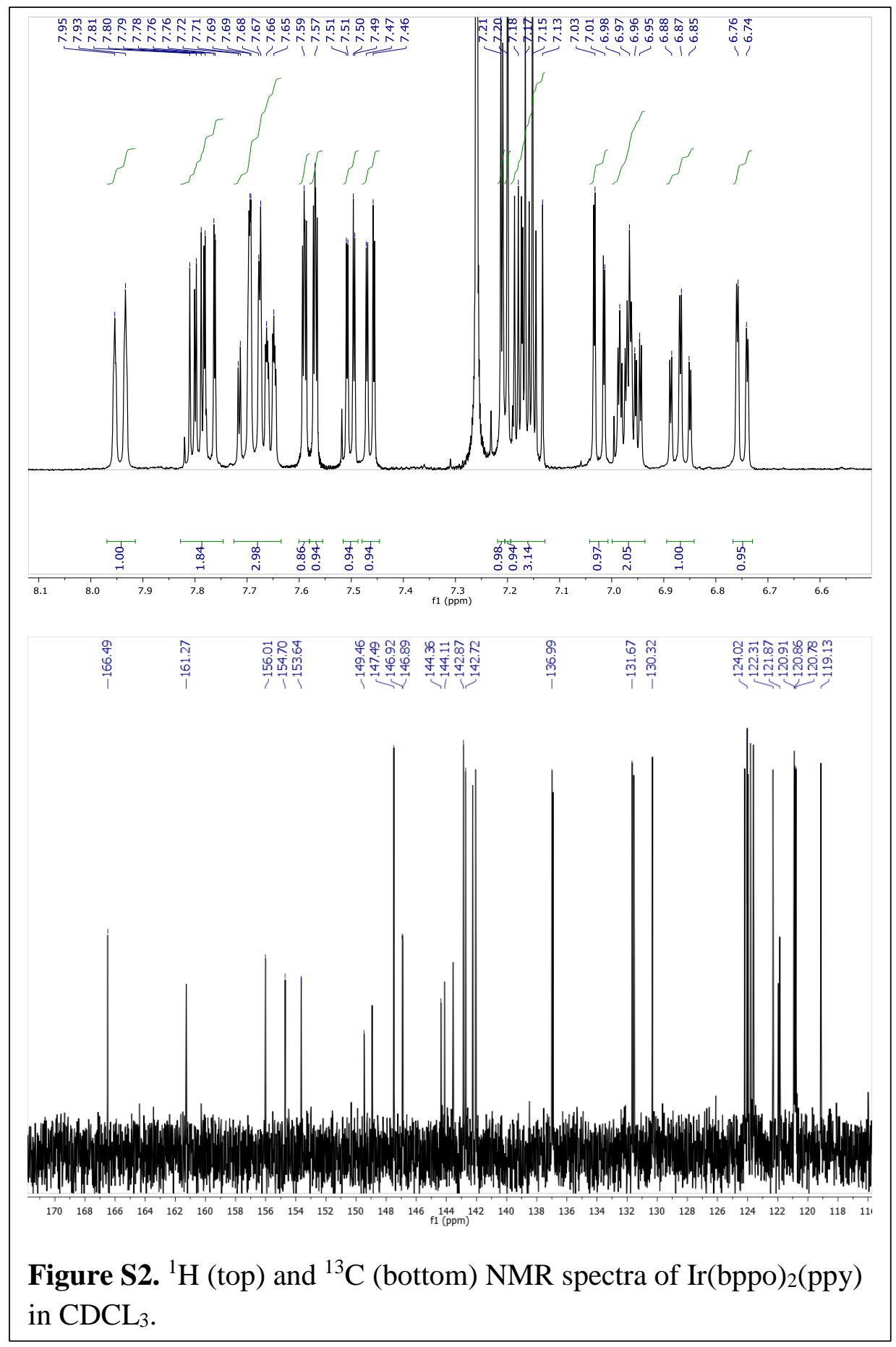




\section{Photophysical Spectra}
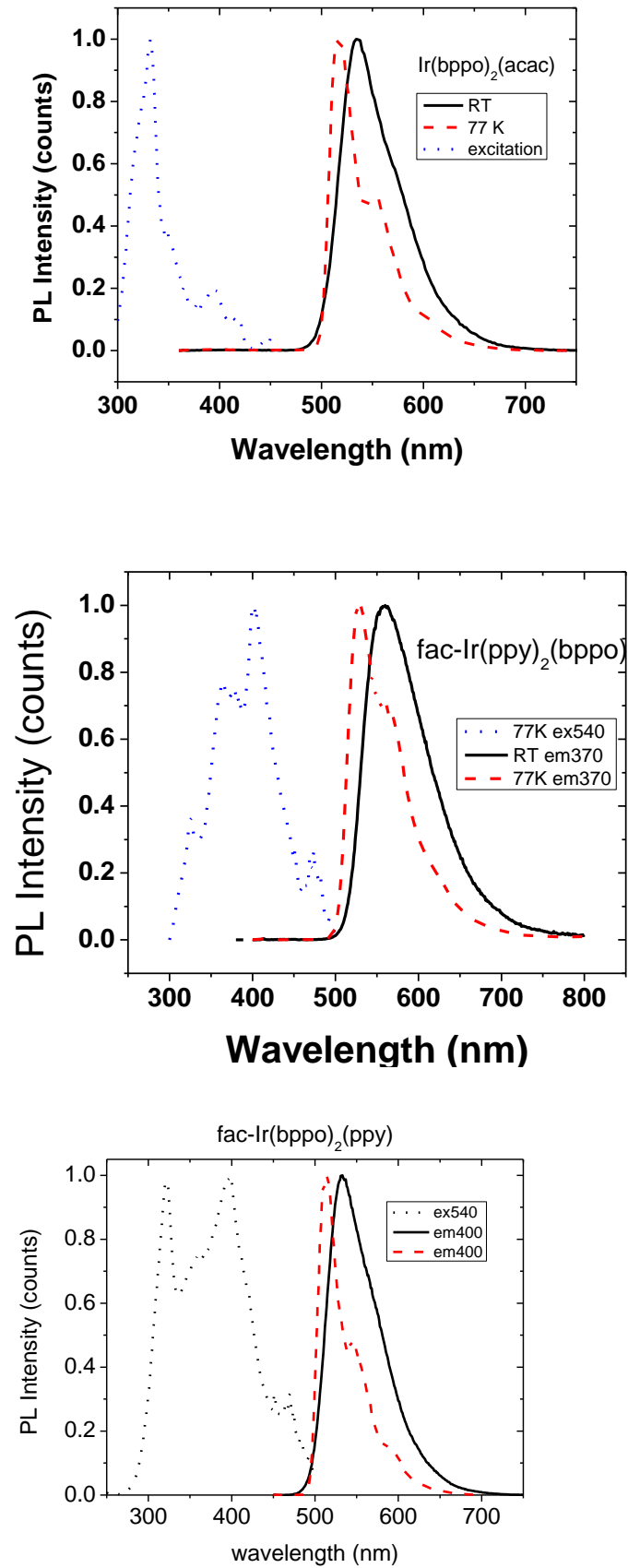

Figure S3. Photoluminescence spectra of compounds in degassed 2-Me-THF. 


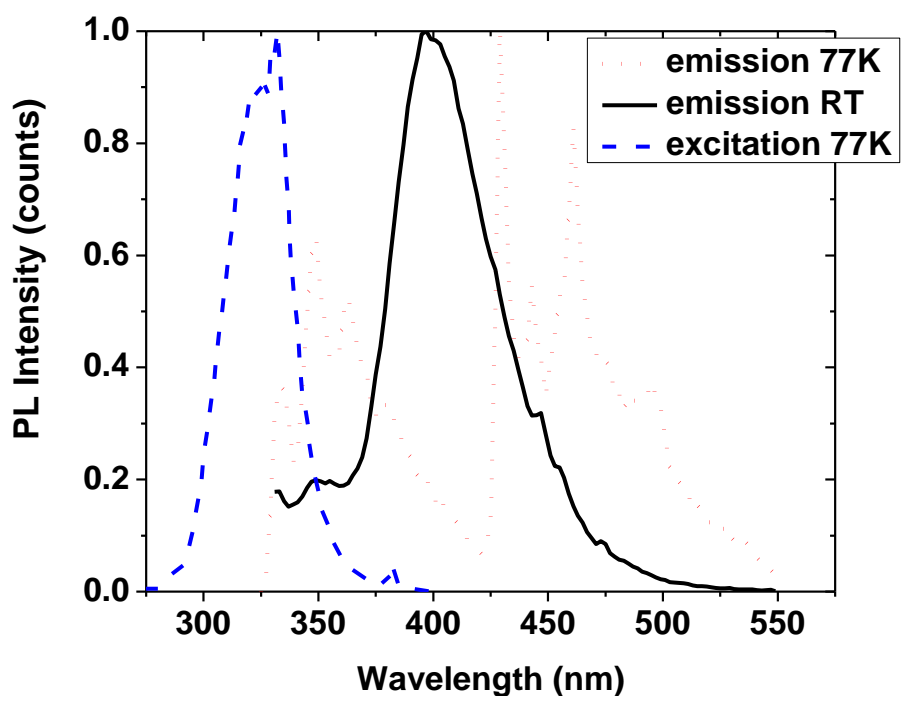

Figure S4. Photoluminescence spectra of bppo ligand in degassed 2Me THF.

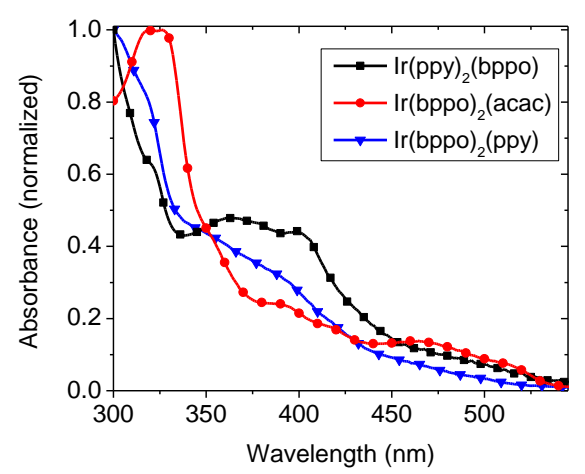

Figure S5. Absorption spectrum in degassed 2-methyl THF at room temperature. UV-visible absorption spectra feature a strong ligand centered $\pi-\pi^{*}$ transition in the ultraviolet with weaker metal-to-ligand charge transfer (MLCT) transitions appearing between 350 and $450 \mathrm{~nm}$. 


\begin{tabular}{|lrlll|}
\hline & $\begin{array}{l}\text { Lifetime (RT) } \\
\text { (us) }\end{array}$ & $\begin{array}{l}\text { Lifetime (77K) } \\
\text { (us) }\end{array}$ & $\begin{array}{l}\text { Quantum Yield } \\
\text { (\%) }\end{array}$ \\
$\operatorname{lr}($ bppo)2(acac) & 1.9 & 7.9 & 68 \\
$\operatorname{Ir}($ ppy)2(bppo) & 1.3 & 5.7 & 88 \\
$\operatorname{lr}($ bppo)2(ppy) & 1.6 & 9.2 & 93 \\
& & & \\
Table S2. Photophysical data of compounds & &
\end{tabular}




\section{$\underline{\text { Electrochemistry }}$}

(bppo) $)_{2} \operatorname{Ir}(\mathrm{acac})$ shows reversible reductions at $-2.06 \mathrm{~V}$ and $-2.29 \mathrm{~V}$ and a reversible oxidation at $0.69 \mathrm{~V}$ (vs. $\mathrm{Fc}^{+} / \mathrm{Fc}$ ) by cyclic voltammetry. (bppo) $)_{2} \operatorname{Ir}(\mathrm{ppy})$ shows reversible reductions at -2.12 $\mathrm{V}$ and $-2.31 \mathrm{~V}$ and a reversible oxidation at $0.63 \mathrm{~V}\left(\mathrm{vs} . \mathrm{Fc}^{+} / \mathrm{Fc}\right)$. (ppy) ${ }_{2} \operatorname{Ir}(\mathrm{bppo})$ shows a fully reversible reduction at $-2.19 \mathrm{~V}$ and a quasi-reversible reduction at $-2.77 \mathrm{~V}$ with a reversible oxidation at $0.48 \mathrm{~V}$ (vs. $\left.\mathrm{Fc}^{+} / \mathrm{Fc}\right)$. The reversible oxidations are assigned to a metal centered oxidation and the observed reductions are to a ligand centered process. The more positive oxidations and more negative reductions relative to classic phosphors is proposed to be a consequence of the introduction of the extremely electron withdrawing coumarin ligands. These strongly $\pi$ electron deficient ligands depresses the HOMO energy but do not change the LUMO as long as the emissive state remains localized on the bppo ligand. Electrochemistry of $\operatorname{Ir}(\mathrm{ppy})_{2}$ (bppo) has been reported previously. ${ }^{4}$ 


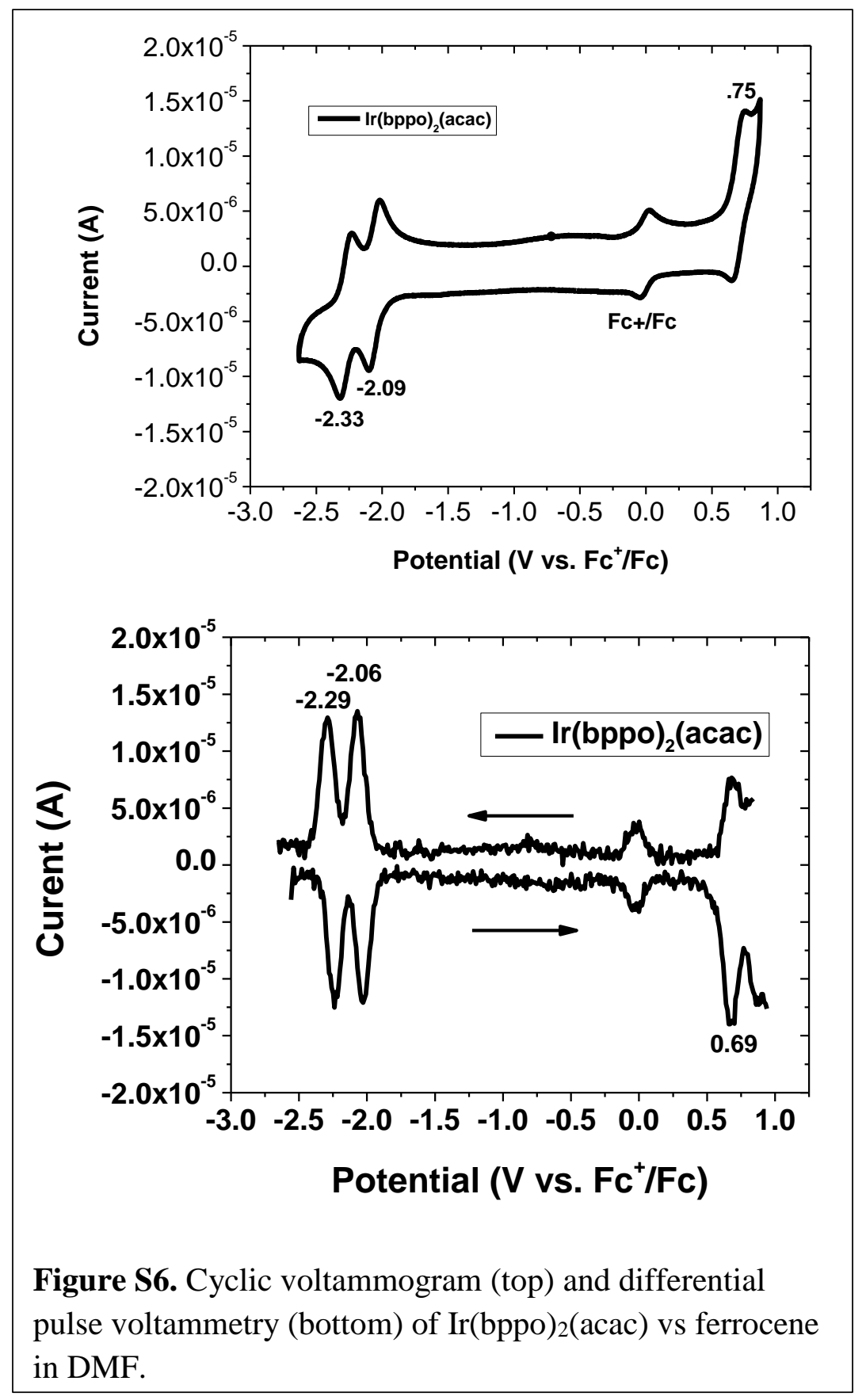



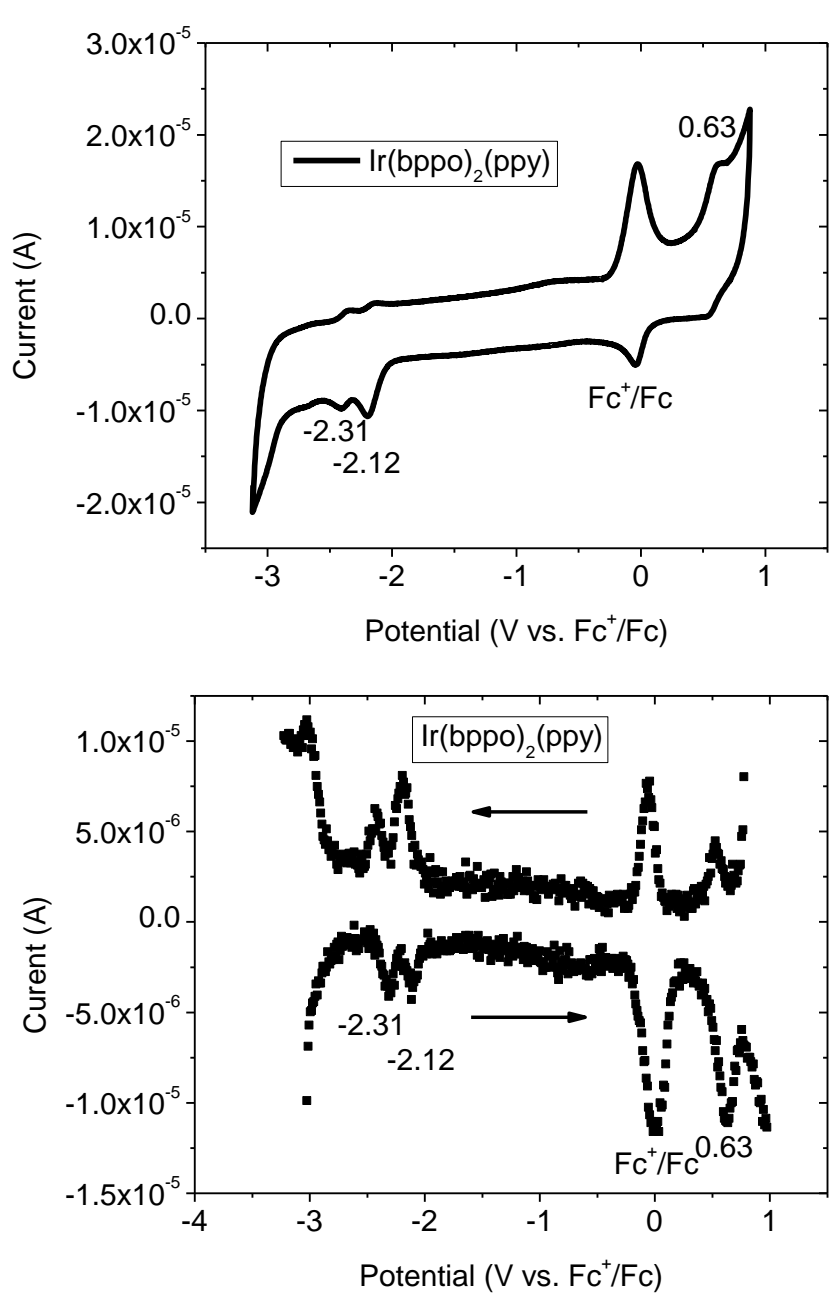

Figure S7. Cyclic voltammogram (top) and differential pulse voltammetry (bottom) of $\operatorname{Ir}(\mathrm{bppo})_{2}$ (ppy) vs ferrocene in DMF. 

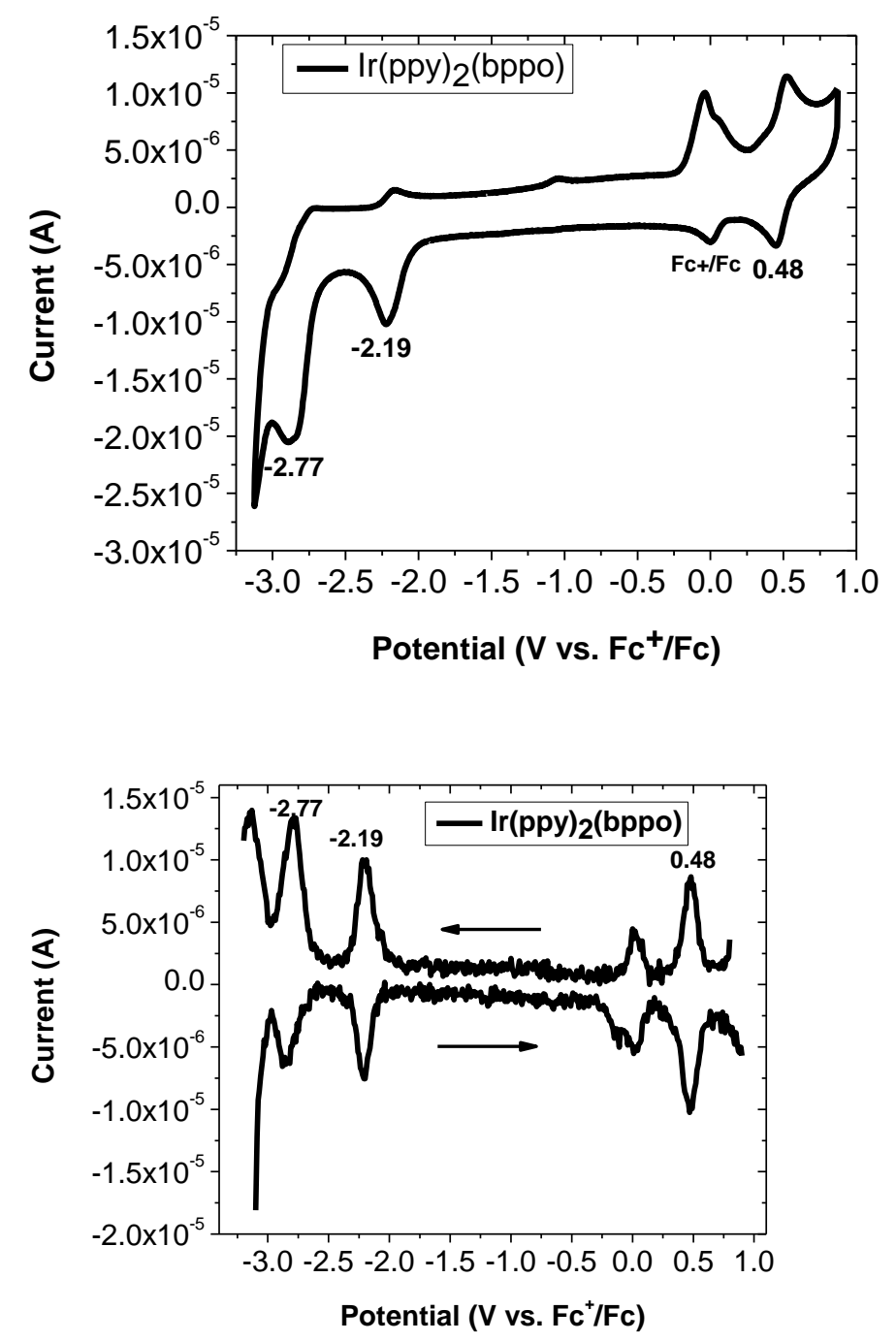

Figure S8. Cyclic voltammogram (top) and differential pulse voltammetry (bottom) of $\operatorname{Ir}(\mathrm{ppy})_{2}$ (bppo) vs ferrocene in DMF. 


\section{Mass Spectra}

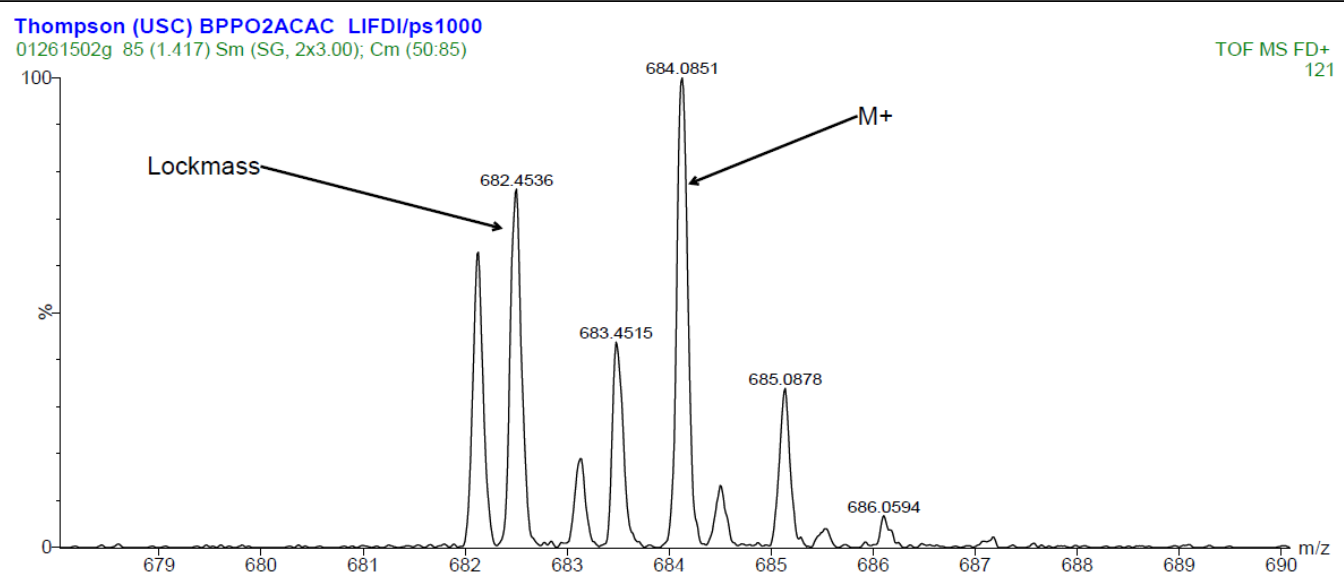

Figure S9. Mass spectrum of $\operatorname{Ir}(\mathrm{bppo})_{2}$ (acac). Recorded by UC Riverside High Resolution Mass Spectrometry Facility. $\mathrm{C}_{29} \mathrm{H}_{19} \mathrm{IrN}_{2} \mathrm{O}_{6} \mathrm{M} / \mathrm{Z}$ calculated 684.0872, found: 684.0851

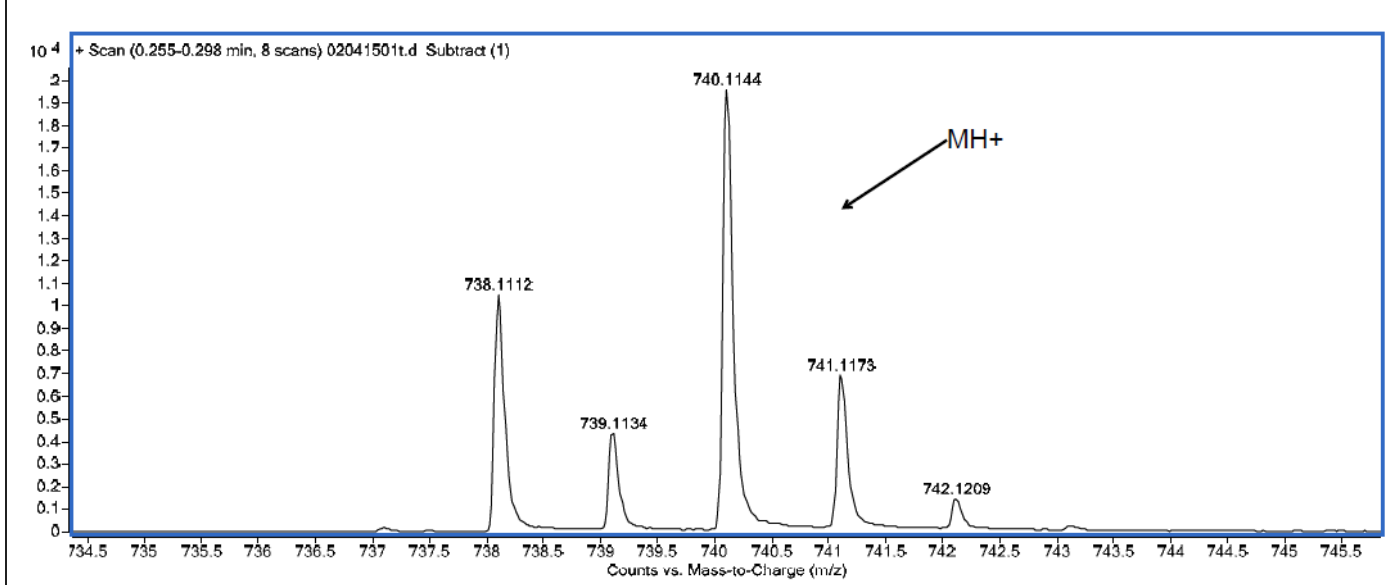

Figure S10. Mass spectrum of Ir(bppo $)_{2}(\mathrm{ppy})$. Recorded by UC Riverside High Resolution Mass Spectrometry Facility. $\mathrm{C}_{35} \mathrm{H}_{20} \mathrm{IrN}_{3} \mathrm{O}_{4}$ Calculated M/Z: 739.1083; found: $\left(\mathrm{MH}^{+}\right) 740.1144$ 


\section{Theoretical Calculations}

Calculations were performed using Jaguar 8.4 (release 17) software package on the Schrodinger Material Science Suite (v2014-2). ${ }^{8}$ Gas-phase geometry optimization was calculated using B3LYP functional with the LACVP** basis set as implemented in Jaguar. ${ }^{9-11}$

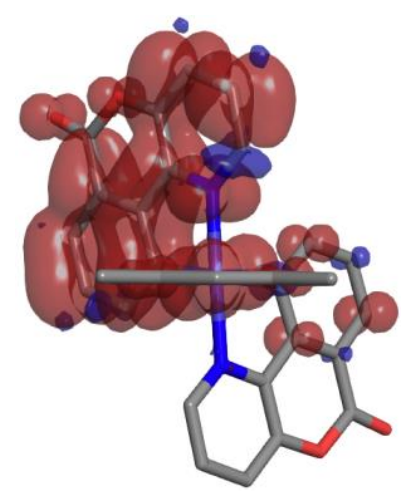

(bppo) $)_{2} \operatorname{Ir}(\mathrm{acac})$

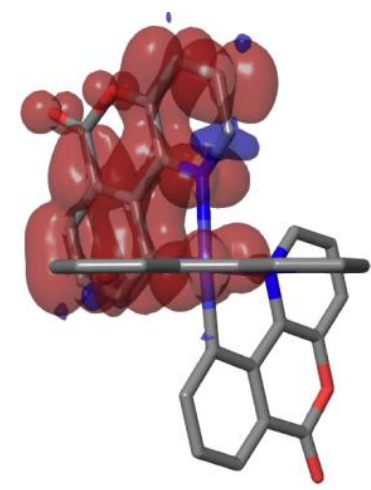

(bppo) $)_{2} \operatorname{Ir}($ ppy)

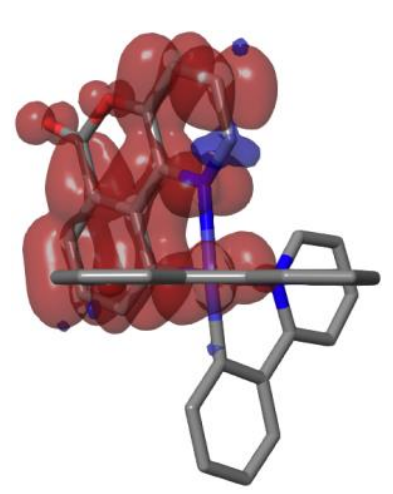

(ppy) $)_{2} \operatorname{Ir}(\mathrm{bppo})$

Figure S11. Triplet spin density surfaces calculated for the Ir dopants (isovalue $=-0.05$ ). The emissive transition is from a ${ }^{3}$ MLCT state. 


\section{Film Emission vs. Concentration}

Normalized photoluminescence of CBP films doped at various concentrations.

A)

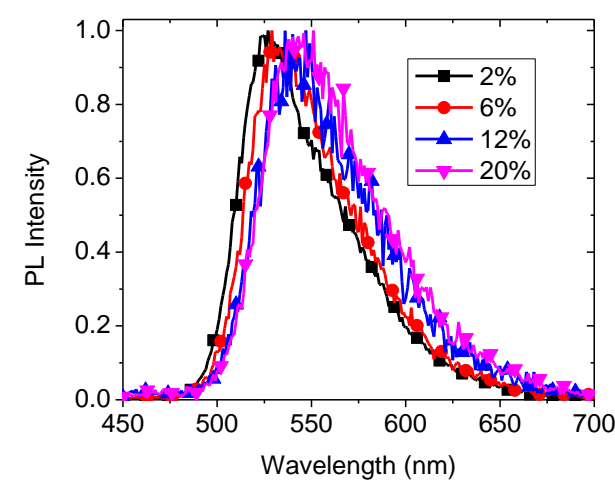

B)

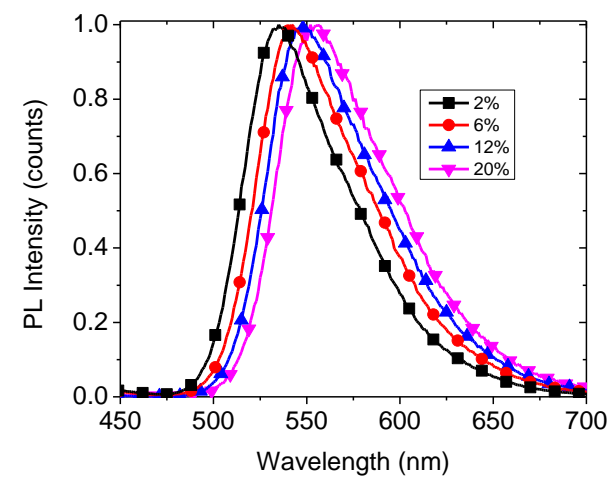

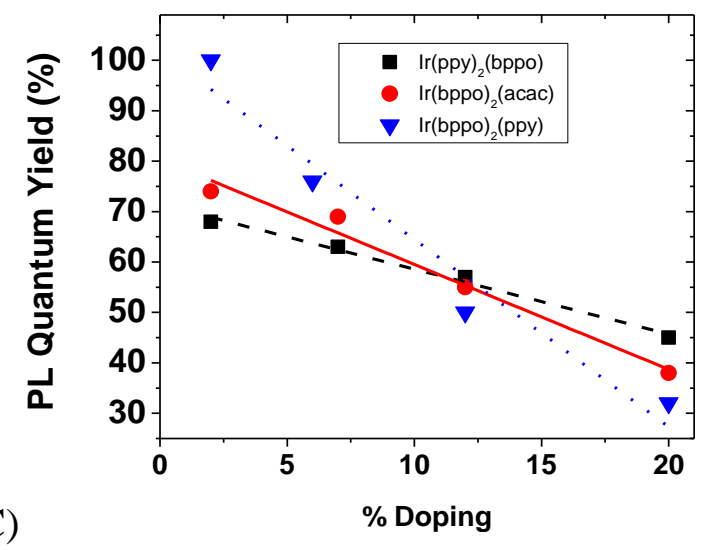

Figure S12. Normalized photoluminescence of CBP films doped at various concentrations with (A) $\operatorname{Ir}(\mathrm{bppo})_{2}$ (ppy) and (B) $\operatorname{Ir}(\mathrm{ppy})_{2}$ (bppo). C) Photoluminescent quantum yield of CBP films doped with varying percentages of phosphors. 


\section{Interaction Potentials}

Values were calculated from $U(\mu, r) \propto-\frac{\mu^{2}}{r^{3}}$ where $\mu$ and $r$ were extracted from theoretical calculation. Value $r$ is the side length of a cube containing the entire molecule. $U / U_{\text {Ir(ppy) } 3}$ value offers a direct comparison to the common isotropic phosphor facial $\operatorname{Ir}(\mathrm{ppy})_{3}$

\begin{tabular}{|l|c|c|c|c|c|}
\hline & $r(\mathrm{~A})$ & $\mu(\mathrm{D})$ & $U$ & $\theta$ & $U / \mathrm{U}_{\text {Ir(ppy)3 }}$ \\
\hline $\operatorname{Ir}(\mathrm{ppy})_{3}$ & 11.95 & 6.31 & 0.023 & 0.33 & 1.00 \\
\hline $\operatorname{Ir}(\mathrm{ppy})_{2}(\mathrm{acac})$ & 11.82 & 2.19 & 0.003 & 0.24 & 0.12 \\
\hline $\operatorname{Ir}(\mathrm{bppo})_{2}(\mathrm{acac})$ & 11.98 & 6.21 & 0.022 & 0.22 & 0.96 \\
\hline $\operatorname{Ir}(\mathrm{bppo})_{2}(\mathrm{ppy})$ & 11.99 & 8.37 & 0.041 & 0.33 & 1.74 \\
\hline $\operatorname{Ir}(\mathrm{ppy})_{2}$ (bppo) & 11.97 & 8.29 & 0.040 & 0.32 & 1.72 \\
\hline
\end{tabular}

Table S3. Calculated interaction potentials for listed compounds. 


\section{Anisotropy Measurements}

Exemplary polarized emission spectroscopy measurement of $15 \mathrm{~nm}$ spin cast film of $\operatorname{Ir}(\mathrm{mdq})_{2}$ (acac) demonstrating nearly isotropic orientation.

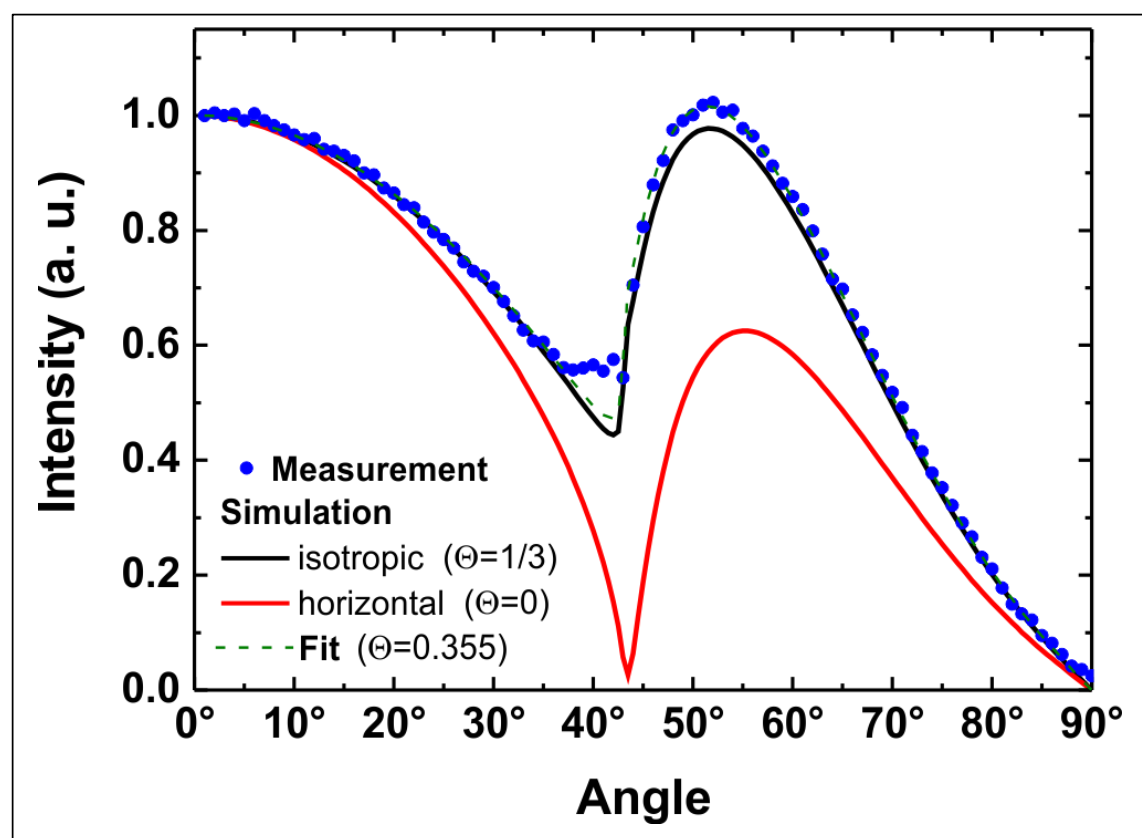

Figure S13. P-polarized emission spectrum of solution processed films of $8 \% \operatorname{Ir}(\mathrm{mdq}) 2(\mathrm{acac})$ in NPD cast films were fit to an anisotropy value of $\Theta=0.36$ 


\section{$\underline{\text { Atomic Force Microscopy }}$}
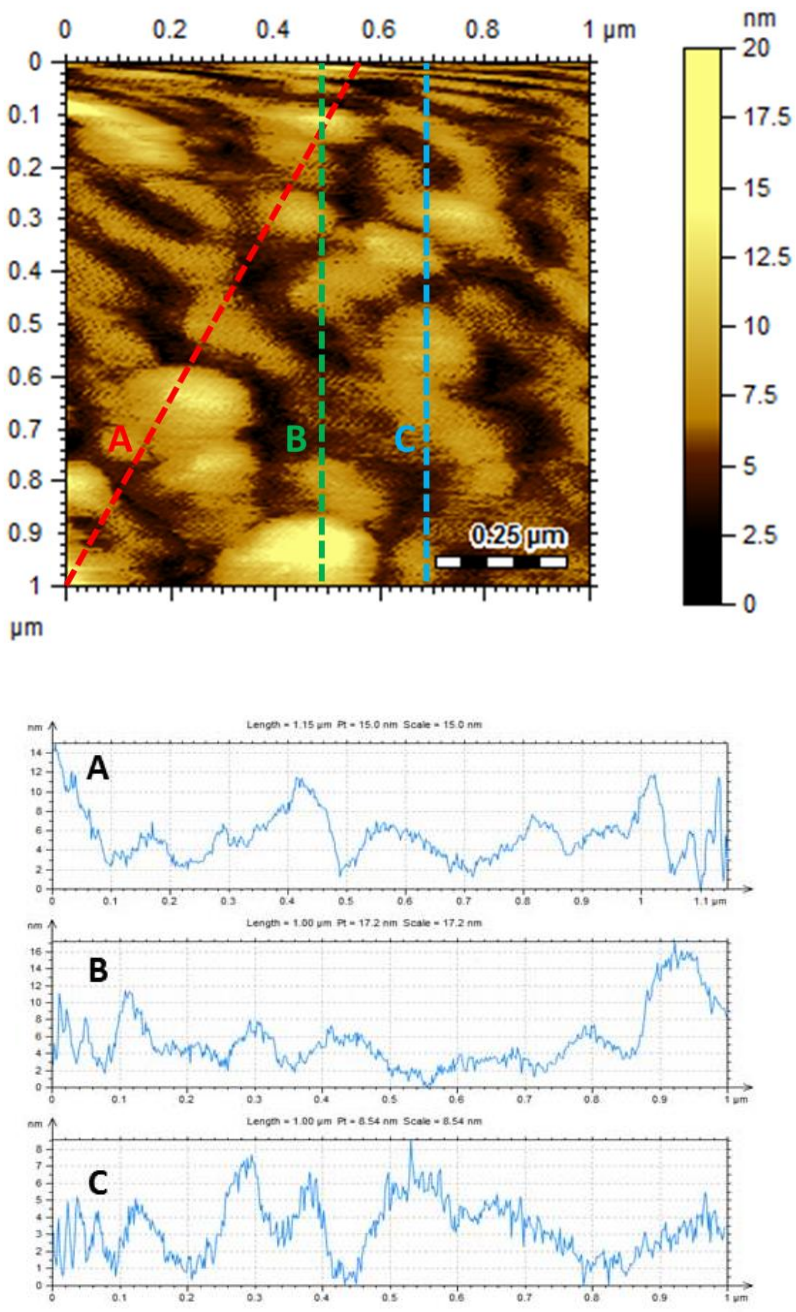

Figure S14. Atomic force microscopy (AFM) traces of a 20nm film of CBP doped with $8 \% \operatorname{Ir}(\mathrm{bppo})_{2}$ (acac) on clean glass. RMS roughness is $2.2 \mathrm{~nm}$. The average angle of the surface is $5.2^{\circ}+/-0.3^{\circ}$. 


\section{Orientation Maps}

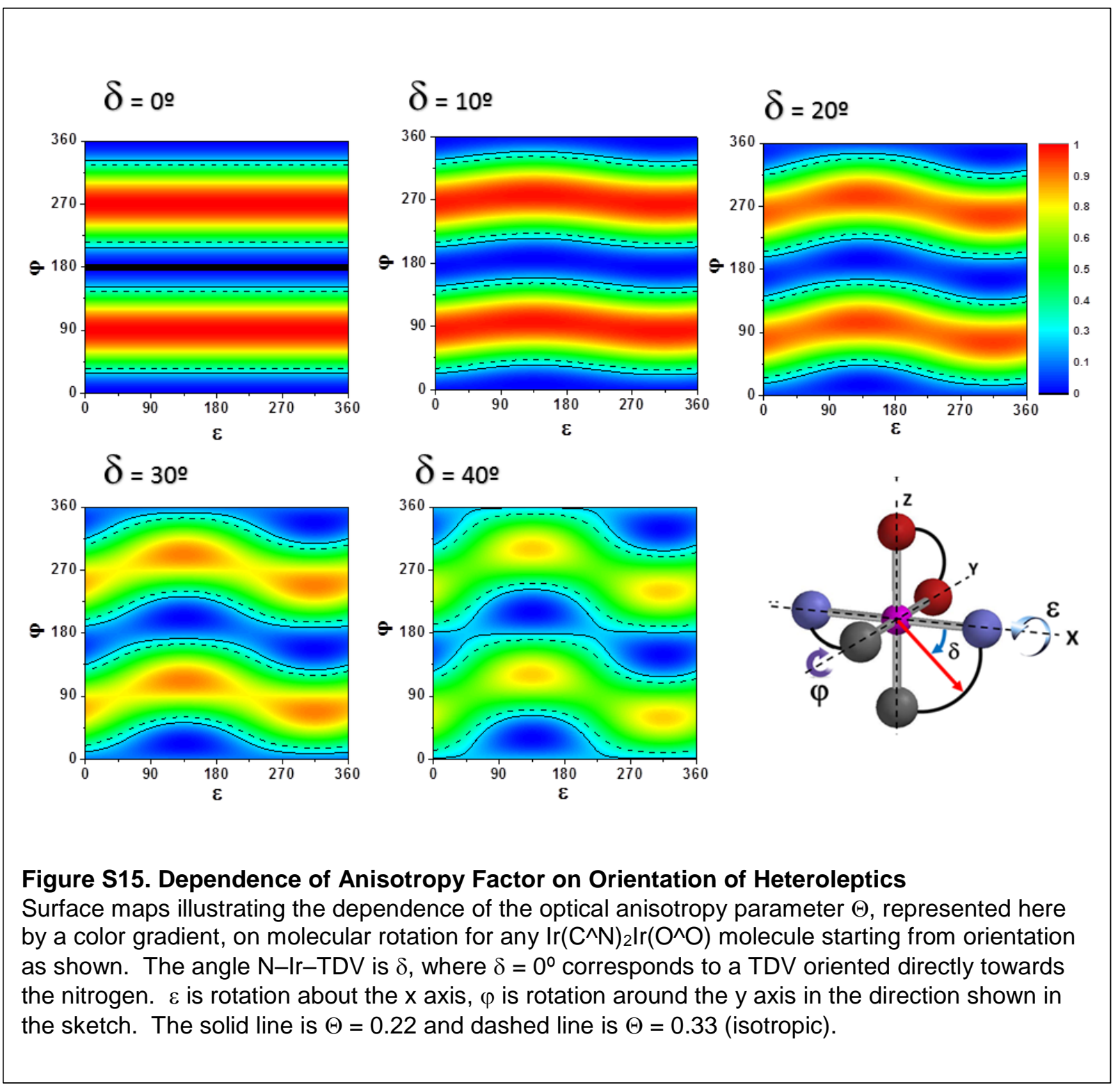




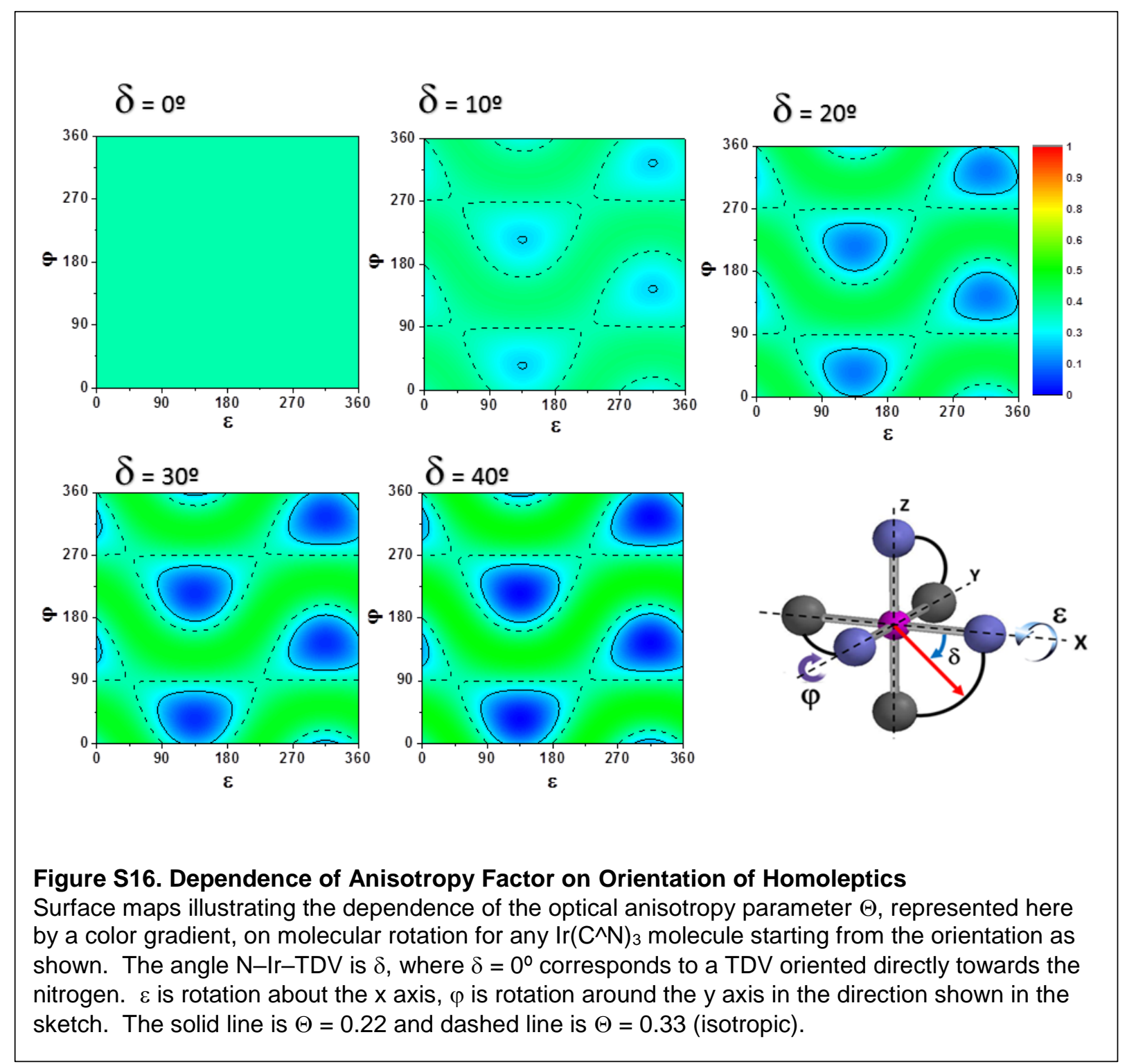




\section{BIBLIOGRAPHY}

(1) Graf, A.; Liehm, P.; Murawski, C.; Hofmann, S.; Leo, K.; Gather, M. C. Journal of Materials Chemistry C 2014, 2, 10298.

(2) Liehm, P.; Murawski, C.; Furno, M.; Lüssem, B.; Leo, K.; Gather, M. C. Applied Physics Letters 2012, 101.

(3) Kim, K.-H.; Moon, C.-K.; Lee, J.-H.; Kim, S.-Y.; Kim, J.-J. Advanced Materials 2014, 26, 3844 .

(4) Ren, X.; Kondakova, M. E.; Giesen, D. J.; Rajeswaran, M.; Madaras, M.; Lenhart, W. C. Inorganic Chemistry 2010, 49, 1301.

(5) Kim, S.-Y.; Jeong, W.-I.; Mayr, C.; Park, Y.-S.; Kim, K.-H.; Lee, J.-H.; Moon, C.-K.; Brütting, W.; Kim, J.-J. Advanced Functional Materials 2013, 23, 3896.

(6) Frischeisen, J.; Yokoyama, D.; Endo, A.; Adachi, C.; Brütting, W. Organic Electronics 2011, 12, 809.

(7) Kim, K.-H.; Lee, S.; Moon, C.-K.; Kim, S.-Y.; Park, Y.-S.; Lee, J.-H.; Woo Lee, J.; Huh, J.; You, Y.; Kim, J.-J. Nat Commun 2014, 5.

(8) version 8.4r17 ed.; Schrödinger, LLC: New York, 2014.

(9) Becke, A. D. The Journal of Chemical Physics 1993, 98, 5648.

(10) Hay, P. J.; Wadt, W. R. The Journal of Chemical Physics 1985, 82, 270.

(11) Stephens, P. J.; Devlin, F. J.; Chabalowski, C. F.; Frisch, M. J. The Journal of Physical Chemistry 1994, 98, 11623.

(12) Flämmich, M.; Frischeisen, J.; Setz, D. S.; Michaelis, D.; Krummacher, B. C.; Schmidt, T. D.; Brütting, W.; Danz, N. Organic Electronics 2011, 12, 1663.

(13) Lee, J.-H.; Sarada, G.; Moon, C.-K.; Cho, W.; Kim, K.-H.; Park, Y. G.; Lee, J. Y.; Jin, S.-H.; Kim, J.-J. Advanced Optical Materials 2014, 3, 211. 